\title{
Long-term vegetation dynamics of a tropical megadelta: Mid-Holocene palaeoecology of the Orinoco Delta (NE Venezuela)
}

Encarni Montoya a, ${ }^{\mathrm{a}}$, Jordi Pedra-Méndez ${ }^{\mathrm{a}}$, Esther García-Falcóa ${ }^{\mathrm{a}}$, Miriam Gómez-Paccard ${ }^{\mathrm{a}, \mathrm{b}}$, Santiago Giralt $^{\mathrm{a}}$, Teresa Vegas-Vilarrúbia ${ }^{\mathrm{c}}$, Fred W. Stauffer ${ }^{\mathrm{d}}$, Valentí Rulla

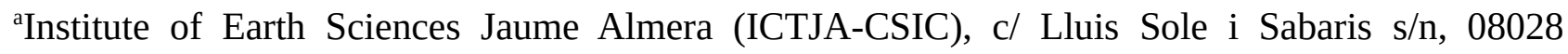
Barcelona, Spain

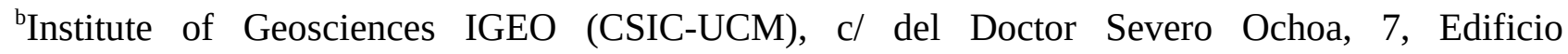
Entrepabellones 7 y 8, 28040 Madrid, Spain

${ }^{c}$ Dep. Evolutive Biology, Ecology and Environmental Sciences, University of Barcelona, Av. Diagonal 643, 08028 Barcelona, Spain

${ }^{\mathrm{d}}$ Conservatory and Botanic Gardens of Geneva, Geneva, Switzerland

\section{ABSTRACT}

Coastal wetlands have been proposed as highly threatened by the ongoing and future climatic change, including projected sea-level changes as an additional forcing factor compared to more inland locations. The limited knowledge generated to date in this topic has been primarily focused on those areas attaining a high population density, and rarely deals with long-term ( $>50$ years) dynamics. Here we present the first Holocene palaeoecological study carried in the Orinoco Delta, in NE Venezuela. The record presented here contains sediments from the last 6200 years and is located in a river-shore swamp dominated by the palm Mauritia flexuosa. Current human occupation is almost restricted to small settlements of the Warao indigenous culture, closely related to the use of $M$. flexuosa and other palm species present in the zone. The results show the occurrence of three well-distinguished palynological zones: (i) from 6200 to 5200 cal yr BP, 
characterised by mixed rainforest and other taxa related to salinity (coastal-like), low (negative) values of magnetic susceptibility and magnetic grain size, absence of transported clays, and the highest macrocharcoal particles abundance; (ii) from 5200 to 2950 cal yr BP, marked by a replacement of the mangrove-like vegetation by a more inland mixed-swamp forest community with low levels of charcoal, and (iii) from 2950 cal yr BP to present-day, characterised by the establishment of the current vegetation community, dominated by M. flexuosa, and an increasing trend in the charcoal curve since the last 700 years. A combination of regional (climatic changes) and local (sediment ontogeny) has been proposed as the key drivers influencing the vegetation succession recorded. The stabilisation of the sea-level that occurred during the mid-Holocene would have favoured the transgression of the coastal line, with the migration of the coastal-like vegetation seawards. Synchronous to this event, a trend towards drier conditions has been reported in the close Cariaco record, that could have also influenced the vegetation replacement. Between 3800 and 2800 years ago, the increased ENSO variability registered in Cariaco may have played a key role in the expansion of the Mauritia palm community. It is suggested that in our location, the potential inhabiting human populations were differently influenced by these environmental changes. First, the disappearance of the coastal resources could have favoured land abandonment, whereas the increase in the abundance of the palm might be influential for the arrival of other inland cultures that were previously used to manage Mauritia. This sequence shows the importance of the ecosystem services for the location inhabitants, highlighting the abandonment of the mid-Holocene culture coeval with the disappearance of its ecosystem. These results also provide information about the sensitivity and resilience in facing external stressors of both humans and vegetation, and will be valuable tools for managing the future of this ecosystem. 


\section{Introduction}

Current climate change is a global phenomenon that will have a devastating influence on the planet and the way we perceive it nowadays (IPCC, 2013). As an attempt of anticipating, the IPCC last report highlights the importance of studying the dynamics occurred in the past that are preserved in the fossil sedimentary records as analogues to infer potential future directions that the Earth system may take (IPCC, 2013). Within the study of climate change in the long-term ( $>50$ years), the analysis of the biota responses to those changes is equally needed.

Studies of long-term vegetation dynamics through palynology have been performed for the last 100 years (von Post, 1916), however, this research has been and currently continues being geographically patchy. In this sense, research efforts in the tropics are qualitatively underrepresented compared to more temperate locations such as Europe or North America (Grimm et al., 2007; Flantua et al., 2015). Some handicaps often lie in the accessibility, availability and suitability of the study sites among other potential impediments (e.g., Rull et al., 2008). Within tropical South America, tropical lowlands hold some of the most biodiverse ecosystems (Myers et al., 2000), so long-term vegetation dynamics' studies are needed to understand the functioning and conservation of these globally important areas. Moreover, recent advances in the increased number of both the techniques applied and locations studied in the region have highlighted a heterogeneous human occupancy pattern prior the European invasion. This lately observed occupancy may have played in some areas a key role in shaping the current landscapes and diversity (Koch et al., 2019; Montoya et al., in press), which might be important when analising the resilience of a given ecosystem in facing perturbations. In this sense, studies of past human occurrence and their subsistence style or landscape management are crucial to understand the past, current and future vegetation dynamics. 
Within tropical lowlands, deltas are transitional terrestrial-aquatic systems in which the landform configuration, water budget, and ecosystems reflect the balance of inputs and outputs associated with interacting climatic, upland, river, and marine processes (Warne et al., 2002a). These transitional settings typically respond quickly and markedly to even modest changes in water and sediment inflow and throughflow, as well as to other environmental parameters' shifts (França et al., 2016, 2019). Human modifications can also disrupt the balance of natural processes (typically fresh water and sediment supply) and thereby initiate a series of adverse impacts on delta ecosystems (Warne et al., 2002a). Deltas and coastal wetlands in general have been proposed as highly threatened by the ongoing and future climatic change, including projected sea-level changes as an additional forcing factor compared to more inland locations (IPCC, 2013; Vegas-Vilarrúbia and Rull, 2016). The limited knowledge generated to date in this topic has been primarily focused on those megadeltas attaining a high population density in the present-day, and rarely deals with longterm dynamics (Vegas-Vilarrúbia et al., 2015; Vegas-Vilarrúbia and Rull, 2016). Here we present the first Holocene palaeoecological study carried out in the Orinoco Delta, in NE Venezuela, an underpopulated and not massively disturbed so far tropical megadelta (Vegas-Vilarrúbia and Rull, 2016). The long-term dynamics of the deltaic vegetation will be explored based on pollen analysis, and supported by charcoal and stable isotope analyses on bulk organic matter. Furthermore, geochemical (diffraction X-ray) and rock-magnetic data will be used to derive potential palaeoclimatic and palaeoenvironmental inferences. Emphasis will be placed on diversity and stability dynamics, as well as to identify the drivers that may have triggered such dynamism. The sensitivity and resilience of the deltaic vegetation as well as the nature of the forest components will be discussed framed within the ongoing climatic change scenario.

\section{Study area and methodology}

\subsection{Study area}


The Río Orinoco is amongst the largest rivers of South America, with headwaters in the Guiana Shield region of Sierra de Parima (in the Brazilian - Venezuelan border) and discharging into the Atlantic Ocean. The drainage basin area is widely known as Orinoquia, and comprises $1.1 * 10^{6} \mathrm{~km}^{2}$ mainly shared by Venezuela and Colombia (Warne et al., 2002a). In NE Venezuela, the Río Orinoco's mouth forms a wide triangular to trapezoidal delta that branches into hundreds of rivers and channels (locally known as caños) intermingled with vast extents of swampy forests composing the lower Orinoco (Fig. 1). The Orinoco Delta is developed in the Eastern Venezuela Basin (EVB), and has a marked distinction of water and sediment discharges between the eastern and centralnorthwestern delta sections (Warne et al., 2002a,b). The delta is considered as a distinct geomorphological unit and it is located between the NE border of the Precambrian Guiana Shield, the Pleistocene deposits of Mesa formation to the west, the NE mountain system of the Mesozoic Cenozoic Cordillera de la Costa and the Gulf of Paria (Fig. 1) (González, 2011). Climate in the Orinoco basin is controlled by the Intertropical Convergence Zone (ITCZ), with rainfall volumes typically ranging in the delta from 1500 to $2600 \mathrm{~mm} \mathrm{year}^{-1}$ with a slight dry season from January to April, and temperatures between 25 and $28{ }^{\circ} \mathrm{C}$ throughout the year (Huber, 1995a; Warne et al., 2002a). Diurnal tides affect the entire delta plain, with tidal amplitudes between 0.7 and up to $1.1 \mathrm{~m}$ in the mid delta (where the study site is located), and perform the majority of geomorphic work within the channel network (Warne et al., 2002a). The Holocene Orinoco Delta is the latest of a series of stacked deltas that have infilled the EVB since the Oligocene (Warne et al., 2002b). Delta progradation has been accomplished by a combination of distributary avulsion and mudcape progradation, with substantial sediment input from as far as the Amazon system (Aslan et al., 2003). The channel network is highly dynamic, with preliminary radiocarbon dating of major distributaries, such as Caño Mánamo system, resulting in no more than 1500 years old (Warne et al., 2002a; Aslan et al., 2003). The coring site is located in the northwest sector, which is widely spaced with relatively straight channels and tide- and precipitation-dominated within the fluvial-marine 
influenced region of the delta (middle delta). Peat swamps formed by histosols are abundant in the interdistributary plains (Aslan et al., 2003; Vegas-Vilarrúbia et al., 2010). The variety of environmental processes operating in the Orinoco Delta results in a wide range of plant communities, including mangroves, lowland forests, and marshy (herbaceous) vegetation as the most abundant types (White et al., 2002; Vegas-Vilarrúbia et al., 2007; Vegas-Vilarrúbia and López Laseras, 2008; González, 2011). Within forests, coastal and estuarine forests form dense mangroves that occur as the outermost vegetation type along the delta shoreline, as well as landward due to marine water incursions (Warne et al., 2002b). These mangroves are composed of just a few highly specialised tree species, namely Rhizophora mangle (Rhizophoraceae), Avicennia schaueriana (Acanthaceae) and Laguncularia racemosa (Combretaceae). In slightly more inland positions, mature mangrove stands are often mixed with palms (Euterpe spp.) and Pterocarpus officinalis. The zonation of (inland) forest vegetation in the Orinoco Delta is also influenced by the different regimes of flooding that occur, and the forests of the middle delta are characterised by evergreen, seasonally flooded marsh and palm forests dominated by: Symphonia globulifera (Clusiaceae), Virola surinamensis (Myristicaceae), Carapa guianensis (Meliaceae), Pterocarpus officinalis (Fabaceae), Mora excelsa (Caesalpiniaceae), Pachira aquatica (Malvaceae), Mauritia flexuosa, Manicaria saccifera, Euterpe oleracea and Bactris sp. (Arecaceae), and Phenakospermum guyannense (Strelitziaceae), on periodically flooded ground. In some parts of the middle Orinoco Delta, large areas with seasonally flooded shrub and/or palm savannahs are also found. Their herbaceous layer is dominated by flood-resistant grasses such as Leersia hexandra and Imperata brasiliensis. Shrubs are scarce, whereas Mauritia palms are quite abundant and often form extensive colonies representing up to $80 \%$ of the canopy, locally known as morichales (Huber, 1995b; Vegas-Vilarrúbia et al., 2007; González, 2011). This palm has been defined as an Amazonian hyperdominant species (ter Steege et al., 2013), and a post glacial expansion from several microrefugia (sensu Rull, 2009) has been suggested (Rull, 1998a; Rull and Montoya, 2014). 
Contrary to other megadeltas of tropical regions, the Orinoco Delta does not hold a large human population (Vegas-Vilarrúbia and Rull, 2016). Nevertheless, it is the homeland of the indigenous culture called Warao, with a total population of 21,125 people in the 1992-year census, and around 48,770 people in 2011, (Huber, 1995a; INE, 2015). This important indigenous group is skilled in fishing, hunting, and gathering and has an independent linguistic affiliation (Heinen, 1988), and heterogeneous origin (Gassón and Heinen, 2012; Heinen and García-Castro, 2013). They live dispersed in an intricate labyrinth of river channels and creeks of the Orinoco Delta, where they have developed a specialised lifestyle adapted to the frequently inundated and swampy environment (Wilbert and Mandazen Soto, 1997). They make extensive use of the abundant forest resources, particularly the palms Mauritia flexuosa (moriche), that they call "the tree of life" (Heinen et al., 1994e1996), and Euterpe sp. (manaca). Today the Warao are rather acculturated to Venezuelan society, especially in the northwestern sector of the delta, and their lifestyle has been affected strongly by the influences of outside settlers (Heinen, 1975; Huber, 1995a; Huber and Zent, 1995), in some cases associated to extensive cattle exploitation. However, evidence of previous (preColumbian) settlements in the delta is very limited, although archaeological sites of past peoples have been found in the near Trinidad since the early Holocene (Rivera-Collazo, 2019).

Despite being a Biosphere Reserve and a National Park, the Orinoco Delta faces several threats. The construction of the dam El Volcán at Caño Mánamo (Fig. 1) in 1966 by Corporación Venezolana de Guayana (CVG) is considered amongst the more important human impacts in the area (García Castro and Heinen, 1999). The creation of the dam has resulted in increased upstream tidal flow of marine waters and its cascade effects (expansion of mangrove and marine fish population upstream, increased rates of sediment entrapment), increase in water temperatures and decreased in dissolved oxygen in the caños, salinization and acidification of the soils, and clogging of the caños by weedy floating vegetation and its consequences (Warne et al., 2002b; Rondón de Rodríguez et al., 2012). Another important perturbation refers to oil prospection and extraction activities, which occur in the 
delta since 1930s (Vila, 1970). To a much lesser extent, tourism is also present in the region, but has been heavily reduced by the economic and political instabilities faced by the country in the last fifteen years.

\subsection{Methodology}

The coring site is located around $20 \mathrm{~m}$ inland in Caño Tigre $\left(9^{\circ} 30^{\prime} 08.2^{\prime \prime} \mathrm{N}-62^{\circ} 40^{\prime} 55.3^{\prime \prime} \mathrm{W}, 13 \mathrm{~m}\right.$ bsl), near Caño Buja in the boundary between Monagas and Delta Amacuro states (Fig. 1). Currently, the vegetation is characterised by a monospecific palm stand of $M$. flexuosa with some other minor elements including climbing species of Mimosoidae, the palm Desmoncus orthocanthos, Montrichardia sp. and several grass species of Bambusoidae being abundant in the understory. A 141 cm-long sediment core called PATAM18_A12 was extracted from the swamp in February 2012 using a Russian corer (Jowsey, 1966) (Fig. 2). Five samples were selected through the entire sequence and sent to Beta Analytic (Beta) for radiocarbon analysis by accelerator mass spectrometry (Table 1). An age-depth model was constructed using the statistical package "clam" (Blaauw, 2010) in R (R Core Team, 2018), using the calibration curve IntCal.13.14c (Reimer et al., 2013), and the best fit was obtained with smooth spline (Fig. 2). Four modern samples were also collected from different environments occurring in Caño Tigre along a transect to characterise their pollen content (Fig. 1; Table 2). The site selection of these four modern samples was established to represent different plant communities present nowadays in the study area and will be used as modern analogues to compare with the palynological assemblages obtained in the fossil record, in addition to previous studies in nearby locations (Hofmann, 2002; Rull, 1998b; Urrego et al., 2009, 2010).

Samples for pollen analysis (1 cc of wet sediment and $1 \mathrm{~cm}$ thickness) were sampled every four $\mathrm{cm}$ in average and processed using standard methods including $\mathrm{KOH}, \mathrm{HCl}$, and $\mathrm{HF}$ digestions, 
acetolysis and mounting/storing in glycerin jelly (Faegri and Iversen, 1989). Lycopodium spores' tablets (University of Lund batch \# 124961; 12,542 spores/tablet) were added before chemical processing (Stockmarr, 1971). Counting was conducted until a minimum of 300 pollen and spores and the saturation of diversity (Rull, 1987). The pollen sum included all pollen types with the exception of aquatic plants (Cyperaceae, Ludwigia, Myriophyllum, Sagittaria, Utricularia), considered azonal taxa. Identification was based on regional pollen atlases (Roubik and Moreno, 1991; Colinvaux et al., 1999; Bush and Weng, 2006). The plant nomenclature used in this paper follows the APG IV classification (APG IV, 2016), and ecological grouping of the taxa found followed local botanical inventories (Vegas-Vilarrúbia et al., 2007; González, 2011). Charcoal particles were analysed following two different protocols. Micro-charcoal particles were identified and counted in the same palynological slides under the optical microscope, only particles $>5 \mathrm{~mm}$ were considered and two different classes were established based on size: (1) small particles (>5$100 \mu \mathrm{m}$ ), indicative of regional fires due to easy dispersion by wind, and (2) big particles (>100 $\mu \mathrm{m}$ ), indicative of fires occurred at local scale (Whitlock and Larsen, 2001). Macro-charcoal analysis was also performed by first deflocculating $0.5 \mathrm{cc}$ of sediment in $15 \mathrm{ml}$ of a $0.1 \mathrm{M}$ solution of $\mathrm{Na}_{4} \mathrm{P}_{2} \mathrm{O}_{7}$ in cold during 2-3 days and then washed through a sieve at $125 \mu \mathrm{m}$ (Whitlock and Larsen, 2001). The remaining residue was then analysed under a low magnification (20x) microscope in a Bogorov tray and all charcoal particles were recorded, except in samples where the number of charcoal particles was too high, in which case the count was stopped after counting 2600 particles. Particles were identified by their angular form, brittle nature and high reflectivity (Clark and Royall, 1995).

Samples for rock-magnetic analysis were obtained by pushing plastic boxes $(2 \times 2 \times 2 \mathrm{~cm})$ continuously into each drive of the core. The analysis involved measurement of the low-field magnetic susceptibility $(\mathrm{X})$ and of the natural remanent magnetization (NRM) of all samples. Additional rock magnetic properties that were measured include the anhysteretic remanent 
magnetization (ARM) and three isothermal remanent magnetizations that were imparted at $0.1 \mathrm{~T}$ $\left(\mathrm{IRM}_{0.1 \mathrm{~T}}\right), 0.3 \mathrm{~T}\left(\mathrm{IRM}_{0.3 \mathrm{~T}}\right)$ and $1.2 \mathrm{~T}\left(\mathrm{IRM}_{1.2} \mathrm{~T}\right) \cdot \mathrm{X}$ was measured with a Kappabridge KLY-2 (Geofyzica Brno) susceptibility bridge using a field of $0.1 \mathrm{mT}$ at a frequency of $470 \mathrm{~Hz}$. ARM experiments were conducted using a D-Tech 2000 (ASC Scientific) AF demagnetizer. The ARM was applied along the $\mathrm{Z}$ axis of the samples with a dc bias field of $0.05 \mathrm{mT}$ parallel to a peak AF of $100 \mathrm{mT}$. IRM $\mathrm{IR.1}_{\mathrm{T}}$ and $\mathrm{IRM}_{1.2}$ т (SIRM) were imparted using an IM10-30 (ASC Scientific) pulse magnetizer. Magnetizations were measured using a SRM755R (2G Enterprises) three-axis cryogenic superconducting rock magnetometer. All magnetic properties were normalized by the dry weight of the samples. We used different magnetic properties and interparametric ratios to determine variations in the type, concentration, and grain size of magnetic minerals (Evans and Heller, 2003; Thompson and Oldfield, 1986). Magnetic susceptibility (X) has been used as a firstorder indicator of the concentration of magnetic (sensu lato) minerals. S-ratios, defined as IRM $_{0.1}$ ${ }_{\mathrm{T}} / \mathrm{IRM}_{1.2 \mathrm{~T}}$ and $\mathrm{IRM}_{0.3 \mathrm{~T}} / \mathrm{IRM}_{1.2 \mathrm{~T}}$, have been used to indicate the relative concentration of low versus high coercivity minerals and ARM and IRM0.1 T as proxies for the concentration of low coercivity minerals. IRM $\mathrm{I}_{1.2 \mathrm{~T}}-\mathrm{IRM}_{0.1 \mathrm{~T}}$, which is equivalent to the "hard” IRM of Bloemendal et al. (1992) (hereafter referred to as HIRM), has been used as a proxy for the concentration of high coercivity minerals. Finally, the ARM/SIRM ratio has been used to make inferences about relative variations in magnetic mineral grain size, provided that a single magnetic mineral (in this case magnetite) is dominant (Thompson and Oldfield, 1986; Evans and Heller, 2003).

Samples for x-ray diffraction (XRD) were picked every four $\mathrm{cm}$ and dried at $60^{\circ} \mathrm{C}$ in an oven for 48 $\mathrm{h}$ and ground manually using an agathe mortar. Mineralogical analyses were conducted using a SIEMENS D500 automatic x-ray diffractometer $(\mathrm{Cu} k \alpha, 40 \mathrm{kV}, 30 \mathrm{~mA}$ and graphite monochromator). The identification and quantification of the relative abundances of the different mineralogical species present in the samples were conducted using standard procedure (Chung, 1974). The same samples employed for the XRD analysis were also used for the total carbon (TC), 
total nitrogen (TN) (relative standard deviation: $5 \%$ of the measurements), $\delta^{13} \mathrm{C}$ and $\delta^{15} \mathrm{~N}$ analyses (0.2\% analytical precision). These analyses were conducted using a Finnigan DELTAplus TC/EACF-IRMS spectrometer at the Centres Científics i Tecnològics of the Universitat de Barcelona (Barcelona, Spain). The carbonate content of the samples was below the detection limit $(<1 \%)$ of the XRD analysis. Therefore, the total carbon (TC) was considered equivalent to the total organic carbon (TOC).

Statistical analyses were performed in R version 3.82 using the packages “vegan” (Oksanen et al., 2013), “rioja” (Juggins, 2017), and “analogue” (Simpson, 2007). For statistical analyses, biological data consisted of the percentages data squared root transformed, with downweight of rare taxa in the ordination analyses. Geochemical data (XRD, rock-magnetism) were standardised. Stratigraphic diagrams were plotted with $\mathrm{R}$ and Psimpoll 4.27 (http://chrono.qub.ac.uk/psimpoll/psimpoll.html) and zonation was performed by “Optimal Splitting by Information Content” (OSIC), using the broken stick method to determine the significant zones (Bennett, 1996). Diversity measures include N0 (richness or species number, also called S), N1 (number of common taxa) and N2 (number of dominant taxa), calculated following Hill (1973), and the evenness ratio N2/N0 after Finsinger et al. (2017). For calculating these indices, the dataset used was the percentage data without downweight of rare taxa in order to capture the total diversity values. A Principal Component Analysis (PCA) was performed considering only the XRD data to characterise the main sedimentary processes that have ruled the sedimentation in the coring site that has not been included in the present paper (scores of axis 1 represented in Fig. 8).

\section{Results}

\subsection{Sediment description, chronology and geochemical data}


The retrieved sediments are composed by greyish to black clays and silty clays with variable proportions of organic matter, which can form brownish centimetre-thick peat layers (Fig. 2). These sediments have been deposited within a floodplain environment. Locally, fine sand centimetre-thick layers have been found, mostly related to punctual avulsion episodes. According to the age-depth model, this sedimentary record contains the environmental history for the last 6200 cal years BP (Fig. 2). Sedimentation rate varies between 0.016 and $0.067 \mathrm{~cm} \mathrm{yr}^{-1}$, providing a sample resolution of 78-154 years per sampling interval.

Fig. 3 shows the geochemical analyses (including different interparametric ratios based on rockmagnetism properties) and will be explained following the statistically significant zones found based on the XRD results. As expected, rock-magnetism indicates that the dominant magnetic mineralogy in the entire sequence is magnetite, as suggested by the IRM/K values obtained and the different concentration parameters' trends observed (Fig. 3), with some punctual inputs of a highcoercivity minerals (most probably hematite) around 25 and $45 \mathrm{~cm}$ of core depth. The coincidence of illite trends with the magnetite content confirms the detrital origin of the second mineral. The base of the record (Zone OR18-A: 141-106.5 cm depth) is characterised by high values of kaolinite and chlorite and absence of illite. Negative values of magnetic susceptibility (MS), characteristic of organic-rich sediments dominated by diamagnetic minerals, is observed in this zone, confirming the geochemical data. Total Carbon (TC) and Total Nitrogen (TN) show the highest values of the entire sequence during this zone, especially from $130 \mathrm{~cm}$ upwards the top of the zone. Together with the increase in TC content a sharp increase in the concentration of low-coercivity minerals (magnetite) is observed. Altogether the results indicate that the ARM (magnetite content) increase observed in the lower part of the sequence cannot be interpreted as a detrital magnetite. Zone OR18-B (106.5-0 cm depth) is marked, in the lower section $(106.5-82 \mathrm{~cm})$, by a decrease in kaolinite and chlorite and increase in illite and quite homogeneous magnetic properties dominated by low-coercivity minerals (e.g. magnetite) of detrital origin. This is confirmed by the clear correlation between the illite 
content and magnetite concentration in the middle part of the section (Fig. 3). This lower interval is also marked by very low values of TC, TN, and TOC/TN. The intermediate section of this zone (82$37 \mathrm{~cm}$ ) is marked by fluctuating trends of kaolinite, illite, chlorite and concentration of detrital magnetite, and a weak recovery, although with still low values of TC and TN. On the other hand, TOC/TN and the isotopic fractions analysed $\left(\delta^{13} \mathrm{C}\right.$ and $\left.\delta^{15} \mathrm{~N}\right)$ show the highest values of the entire record. The observed variations in both concentration of magnetite and grain-size related parameters are probably related to changes in sediment supply and, hence, to environmental conditions. In the upper part of the zone there is a shift towards the values attained at the bottom of Zone OR18-B, with low values of chlorite, kaolinite, TC, TN and TOC/TN and high values of illite and MS. The uppermost $10 \mathrm{~cm}$ of the sequence are marked by an increasing trend of chlorite, quartz, concentration of low coercivity minerals, TC and TN. The opposite trends are observed in illite, which disappears, and in MS probably due to the increase in the TC content and the formation of magnetite of non-detrital origin.

\subsection{Palynological data}

\subsubsection{Modern samples}

The modern samples show distinct palynological assemblages that reflect the different environment and vegetation communities in which they were collected (Table 2; Fig. 4). CT0 is largely characterised by high values of Rhizophora and the fern spore Monolote psilate. Other taxa present are Euterpe, Mauritia, Cecropia, Urticales (now includes in Rosales sensu APG IV; hereafter named as Urticales), Solanaceae and Cyperaceae. CT1 is marked by high values of the palms Mauritia and Euterpe, and to a minor extent, Rhizophora, Monolete psilate, Asteraceae, Cecropia, Combretaceae/ Melastomataceae (Myrtales; hereafter referred as Combrataceae/Melastomataceae) and Cyperaceae. Mauritia pollen attains the maximum values in the modern sample CT2 and obscures the rest of 
palynological taxa signal; this sample was collected at the same location than the sedimentary sequence PATAM18_A12. Sample CT3 is characterised by high values of Poaceae, Monolete psilate, Ficus, Cecropia, Asteraceae and Cyperaceae, with some input from Alchornea, Anthurium and the aquatic plants Ludwigia and Sagittaria. Microcharcoal values are average, being the lowest value obtained in sample CT2, and the highest value in CT3. In relation to the macrocharcoal analysis, values are almost negligible for three of the samples (CT0: 88, CT1: 20, and CT2: 30 particles $\mathrm{Cc}^{-1}$ ), while CT3 attains a high value (2690 particles $\mathrm{Cc}^{-1}$; Fig. 4).

\subsubsection{Sedimentary record PATAM18_A12}

The fossil pollen assemblages obtained in the sedimentary record of PATAM18_A12 delimits three significant zones (Fig. 5). Microcharcoal values follow the same trends than the macro-charcoal analysis, and given the broader geographical provenance of the microcharcoal particles, only the small particles (indicative of fires occurring from a larger spatial scale) have been included in the diagram for comparison.

Zone OR18-1 (103-141 cm; eight samples): The lower zone is characterised, at the bottommost of the section, by high values of Ficus, Myrtaceae, and Asteraceae, which shortly after drop to almost disappear. This zone is then marked by high values of Symphonia, Ilex, Rhizophora, Cassipourea, Asteraceae and Urticales. Monolete psilate and Polypodium verrucate are the most abundant pteridophyte spores, and Acrostichum is, although with low values, only present in this zone throughout the record. The aquatic plants' record shows punctual peaks, such as Sagittaria at the bottom of the zone and Cyperaceae (semi-aquatic) in the upper section. Ludwigia is also present in the upper half with low values. Macrocharcoal particles attain their maximum values during this zone (Fig. 5). 
Zone OR18-2 (63.5-103 cm; sixteen samples): This zone is marked by the disappearance of the previous dominant taxa, high values of Urticales, and the presence of several palms including Euterpe, Mauritia and Desmoncus, appearing the last two taxa for the first time in the record. Alchornea peaks at the middle of the zone, and other minor taxa contributing in a more regular, continuous way, are Ilex (though with lower values than in the previous zone), Asteraceae, Amanoa and Herrania. Besides Ilex, other taxa that show decreased abundances compared to Zone OR18-1 are Myrtaceae and Symphonia, whereas Crudia, Loranthaceae and Paullinia appear in the record at the beginning of the zone. Although with lower values than in the previous zone, Monolete psilate, Polypodium verrucate and Cyperaceae are the more representative taxa outside of the pollen sum, with some punctual appearance of Salvinia-t and Actinotaenium. The charcoal values are very low, and a subtle increase is observed at the upper half of the zone.

Zone OR18-3 (0-63.5 cm; twenty-six samples): The upper zone is marked by the lowest values of taxa previously abundant like Urticales and Ilex, and the dominance of Mauritia. This zone is divided into two subzones: OR18-3a (18.5e63.5 cm; eighteen samples) and OR18-3b (0e18.5 cm; eight samples). Sub-zone OR18-3a is defined by a sudden and marked increase in Mauritia abundances that reach up to $60 \%$ of the total pollen sum. Other taxa contributing to a minor extent include Anthurium, Euterpe and Asteraceae. Towards the upper half of the subzone, there is an increase in the abundance of taxa related to water, such as Salvinia-t, and the algae Actinotaenium and Mougeotia. The split of this upper zone responds to the marked appearance of several taxa only in the sub-zone OR18-3b, such as Combretaceae/Melastomataceae and Spathiphyllum. The uppermost sub-zone is also characterised by a marked increase in the charcoal record and a decrease in the algal remains that appeared in the previous subzone OR18-3a.

\subsection{Statistical analyses}


The similarity between the pollen assemblages obtained in the modern and fossil samples has been tested with three different statistical analyses (Fig. 6: analogue matching and close analogues (AMCA), Detrended Correspondence Analysis (DCA), and time-tracker). The AMCA technique defines the occurrence of analogues based on the similarities found between the modern and the fossil assemblages' composition (Simpson, 2012). DCA biplot shows the fossil and modern samples data treated as being the same dataset. In the timetracker ordination analysis the modern samples are used for defining the spatial framework where to display the fossil samples, and those fossil samples are connected following the stratigraphical order (Simpson, 2007). AMCA plot shows all the fossil samples that have one or two modern samples analogues, which are mostly restricted to the upper zone OR18-3. In the DCA analysis the fossil samples are clustered and well defined following the palynological zones observed. Regarding the display of the samples in the DCA plot, it is noteworthy that the palynological zones OR18-1 and OR18-2 do not have any modern sample related. The same is also shown in the timetracker ordination analysis, where modern samples CT-0 and CT-3 appears much farer to the fossil sequence samples than CT-1 and CT-2. Altogether the three analyses interpretation shows that only the upper samples from the sedimentary record have modern analogues. Considering the range of modern samples presented (Fig. 4), samples CT-1 and CT-2 act as modern analogues whereas CT-0 and CT-3 do not share enough similarities with any of the fossil samples analysed.

The geochemical data have been plotted as environmental variables in a Redundance Analysis (RDA) against the biological data (fossil pollen) in Fig. 7. The XRD analysis shows illite and quartz at the left of the first axis and chlorite and kaolinite to the right, whereas the second axis splits illite towards the positive values and the rest of variables located at the negative side (Fig. 7A). Within the space defined, the biological data are displayed along the first axis, with samples from the palynological zone OR18-3 located at the left with negative values, followed to the right by the samples belonging to Zone OR18-2 and towards the more positive values of axis one are the oldest 
samples of OR18-1. Such distribution of the pollen samples is also observed in the RDA analysis of the rock-magnetic data (Fig. 7B). In this case, besides the ordination from negative (younger samples) to positive (older samples) values of axis one, there is a difference in the distribution pattern of the samples according axis 2. Whereas the pollen samples from OR18-1 and OR18-2 are located close to zero or negative values of the axis, the younger samples from OR18-3 are widely distributed along the entire axis. Regarding the environmental variables considered, high coercivity minerals, MS and low coercivity minerals are located to the left of axis 1 and the grain size and the high/low coercivity ratio to the right. The second axis divides MS, high coercivity minerals and grain size, located in the positive side of the axis, from low coercivity minerals and the ratio (plotted in the negative side of axis two). Finally, following Meyers (1994), we have plotted the samples according to their values in TOC/TN and $\delta^{13} \mathrm{C}$ to observe the nature of the biological remains found in the sediment. Most of the samples attain TOC/TN ratio values higher than 20 and $\delta^{13} \mathrm{C}$ values between -28 and $-30.5 \%$, which indicates that the organic matter is mainly related to C3 terrestrial plants, except for the samples of zone OR18-1 representing the last 1400 years of the sedimentary record that contain lower values, indicating some algal contribution to the organic matter present in this sequence.

\section{Interpretation \& discussion}

\subsection{Long-term dynamics of deltaic vegetation}

The Mid-Holocene record of the sedimentary archive PATAM18_A12 has shown the high dynamism of the deltaic vegetation of Caño Tigre during the last 6200 years. Although forested through the entire record, the taxa composition has greatly varied through time showing different forest types. 
From 6200 to 5200 cal yr BP, the presence of several salinity tolerant taxa (Rhizophora, Cassipourea and the fern Acrostichum) can be interpreted as the occurrence of a mixed rainforest or swamp forest with mangrove elements (or mangroves occurring nearby), similar to other coastal plant communities found in the Amazon in the recent past (Behling and Lima da Costa, 2000, 2001; Vedel et al., 2006), and today in the lower delta (Vegas-Vilarrúbia and López Laseras, 2008). The area was likely subjected to some tidal influence as indicated by the abundance of Rhizophora and Chenopodiaceae/Amaranthaceae (Urrego et al., 2013), with inundation events being rare as shown by the presence of rainforest elements (Vedel et al., 2006; Vegas-Vilarrúbia et al., 2007). This ancient coastal-like community also presented some disturbance as revealed by the presence of pioneer taxa such as Cecropia, Poaceae, Cyperaceae and Monolete psilate that could indicate some brackish waters or the opening of the understory (Rull, 1998b; França et al., 2012). The presence of Acrostichum (and Chenopodiaceae/Amaranthaceae) on Colombian and Venezuelan mangroves has been previously interpreted as indicative of early successional stages (Vegas-Vilarrúbia, 2000; Urrego et al., 2013), but in the present study both taxa maintained their abundances during a millennium. In addition, the differences between the plant dynamics of pure mangroves and our plant community, currently located at around $50 \mathrm{~km}$ from the coast line, need to be considered when comparing results. Despite the long-dispersion by wind and water of its pollen (Behling et al., 2001), the presence of Rhizophora individuals in the coring site or nearby during this time interval should not be completely ruled out, as mangrove forests have been previously reported in the area since at least $7000 \mathrm{cal}$ yr BP (Rull et al., 1999). In Caño Tigre, we hypothesise the local occurrence of Rhizophora trees, even at low abundances, due to the occurrence of Rhizophora trees in the surroundings of the coring site nowadays (Table 2 \& Fig. 4). Nevertheless, this ancient plant community differed from the current assemblages growing nearby, as it shown by the absence of modern analogues within the samples analysed (Fig. 6). On the contrary, some of the abundant taxa found in this zone are also common elements in today's swamp forest closer to the delta mouth (Vegas-Vilarrúbia and López Laseras, 2008). 
Around 5200 cal yr BP, a vegetation succession took place, dominated by the appearance and establishment of Mauritia. The marked decrease of previously abundant taxa (Symphonia, Ilex, Rhizophora, Cassipourea, Amaranthaceae/Chenopodiaceae, Coursetia) and the increase of others including Urticales, Alchornea, Amanoa, Virola, Anthurrium, Euterpe and Herrania showed the change towards a different assemblage of mixed swamp forest. This forest composition evidenced the occurrence of at least sporadically inundation events (Behling and Lima da Costa, 2000) and was not transitional, as it lasted for more than 2000 years, until approximately 2900 cal yr BP. Similar trends and vegetation composition were found in a close record of French Guiana mangroves and in the N Brazilian coasts (Tissot and Marius, 1992; Behling, 2001; Belhing \& Lima da Costa, 2001). The disappearance of coastal-like communities has been reported for other coastal records during the mid-Holocene. However, these sequences have often registered a replacement by herbaceous vegetation forming marshes instead of a mixed-swamp forest (Behling et al., 2001; Urrego et al., 2013). Some exceptions to this herbaceous replacement are found in more inland records of the $\mathrm{N}$ Brazilian coast, showing a mangrove-like vegetation being replaced by palms (Behling, 2001; Belhing \& Lima da Costa, 2001). The forest taxa composition found in Zone OR18-2 has been previously reported also as a palm-swamp community, but given the evenness of the zone compared to the next one (Fig. 8: ratio N2/N0), we argue that a numerically intermediate importance of Mauritia will be best defined as a mixed-swamp forest (González, 2011; Tissot and Marius, 1992). In this sense, our classification as a mixed-swamp forest agrees with previous botanical surveys of present-day plant communities in the lower Orinoco Delta plain (VegasVilarrúbia and López Laseras, 2008; González, 2011). Altogether, the community replacement nature and dynamics found are in agreement with the hypothesis by Vedel et al. (2006), that highlights that the differences between the successions recorded can rely in the distance of the coring site to the sea. 
Since 2950 cal yr BP onwards, the vegetation of Caño Tigre is represented by a Mauritia-dominated swamp, which is the presentday plant community (indicated by the similarity to the modern samples; Fig. 6). However, once established, several shifts have occurred maintaining the dynamism of the plant community until shaping the present landscape. Noteworthy are: i) the appearance and increase of aquatic elements during the last 1400 years (Fig. 5), high enough to change the isotopic and magnetic signals of the sediment (Fig. 7), and ii) the increase in Combretaceae/Melastomataceae and Spathiphyllum $700 \mathrm{cal} \mathrm{yr} \mathrm{BP.} \mathrm{coeval} \mathrm{to} \mathrm{the} \mathrm{increment} \mathrm{in} \mathrm{the}$ fire occurrence (Fig. 5). Such synchrony points to a possible causal relationship, especially regarding the last taxon, inhabitant of the understory, that will be discussed in the last section of the discussion.

Caño Tigre has shown three different stable plant communities, in the sense of being present in the location without major structural changes during several millennia. It is noteworthy that although the changes occurred were dramatic and probably had profound consequences in the forest structure or ecosystem services provided, they were neither abrupt nor fast. Thus, the coastal-like forest was replaced by a mixed forest between 5400 and 4900 cal yr BP, whereas the expansion of Mauritia and the establishment of the palm swamp took almost 1000 years, between 3800 and 2900 cal yr BP. Nevertheless, these long-term changes are referred to plant community shifts. Regarding individual taxa responses, it can be observed the abruptness in the appearance and expansion of Mauritia, Combretaceae/Melastomataceae or Spathiphyllum, and in the disappearance of Rhizophora, Cassipourea or Urticales, all faster than the centennial sampling resolution performed (Fig. 2). These results are in agreement with previous studies highlighting the need of long-term research in order to observe real plant communities' dynamics applicable to answer todays' ecological and conservation questions (Rull et al., 2013; Vegas-Vilarrúbia et al., 2011). Within the dynamics observed, the expansion of Mauritia occurred around 3000 years ago and the establishment of the current landscape resulted in a less diverse plant community. This is clearly 
appreciated in the diversity indices included (Fig. 8), where despite the total number of species being regular through the entire record (N0), the almost monospecific character of the palm-swamp drastically reduced the evenness of the plant community (N2/N0). Local conditions have been proposed as key drivers of the shift from mixed mangrove-like communities to monospecific assemblages in Colombian coastal records (Urrego et al., 2013), although referred to changes towards mangrove species dominance, not Mauritia's as in the present study. In the following sections, we will infer some of the key drivers responsible for the observed vegetation responses.

\subsection{Ecological consequences of Holocene geomorphology, sea-level and climate changes}

The onset of the Holocene was characterised by a eustatic sea-level around $60 \mathrm{~m}$ below present, and rose at a relatively stable rate until $7000 \mathrm{cal}$ yr BP, with a progressive decrease afterwards to present (Khan et al., 2017). Holocene sea-level changes in the Caribbean show that for the Orinoco region, there was a rapid relative sea-level rise (SLR) in the early to mid-Holocene (from $-6.8 \pm 3 \mathrm{~m}$ at 7.8 cal kyr BP to $-1 \pm 0.9$ by 5.9 cal kyr BP), remaining relatively constant afterwards (Khan et al., 2017). Most of coastal Amazonian palaeoecological studies highlight the importance of Holocene sea-level trends in the past vegetation responses observed (Cohen et al., 2012). Due to the proximity of the coring site to the present coastline (Fig. 1), it is logical to explore the potential effects of sealevel rise on the vegetation dynamics, as it has been highlighted by Behling and Lima da Costa (2000) for Amazonian wetlands not strictly coastal. We suggest that our coring site was located closer to the coastline prior the stabilisation of the sea-level and thus during the occurrence of the coastal-like plant community, according to previous geomorphologic works that have suggested that the northwest region of the Orinoco Delta prograded around 20e30 km during the late Holocene (Aslan et al., 2003). The stabilisation of the sea-level likely provoked the transition from marinedominated sedimentation environment to a fluvial floodplain one with the formation of new soils and the progradation of the coast shoreline (Yulianto et al., 2005). This environmental shift was 
probably involved in the migration of the coastal-like elements seawards as it has been previously reported (Behling and Lima da Costa, 2001; Tissot and Marius, 1992). Considering the potential effect of the sea-level change, there was a delay or time-lag between the driver (sea-level stabilisation) and the ecological response (migration of the coastal-like taxa and appearance and establishment of Mauritia) of about 500 years in Caño Tigre (from 5900 to 5400 cal yr BP). However, it is highly unlikely that the sea-level change acted as the sole force driving the vegetation change. Under this scenario of sea-level and soil stabilisation, regional climatic trends were likely also involved. The Cariaco basin record has proven its usefulness and accuracy in registering supracontinental past climatic trends, and is located very close to our study area (Fig. 1). The titanium (Ti) curve of Cariaco shows a decreasing trend in precipitation and strong El Niño signal around mid-Holocene starting around 5400 cal yr BP (Haug et al., 2001), coinciding with the onset of the vegetation replacement. This is also observed more locally in the scores of PCA first axis of the XRD data (Fig. 8) as well as the geochemical and rock-magnetic data (Fig. 3), that shows the absence of Illite and can be interpreted as some humidity in the soils and negative MS values related to organic-rich sediments. The absence of transported clays and the observed enhanced magnetite content in the lowermost part of the core suggests the presence of authigenic magnetite. We suggest that the replacement of coastal-like elements by a mixed-swamp forest, with the arrival and establishment of Mauritia was influenced by the joint action of at least two interconnected, scale-dependent processes: i) sea-level stabilisation promoting stable conditions for new soil formation (local process), suitable for the arrival of new taxa, and ii) registered precipitation decrease with strong El Niño acting as a trigger (regional process), favouring its establishment with regards to other species (Urrego, 2018). As already mentioned, mid-Holocene mangroves colonisation has been reported in many Caribbean works highlighting the importance of local factors compared to regional sea-level rise in the establishment of coastal plant communities (Urrego et al., 2013). In this sense, Emilio et al. (2014) showed the importance of soil conditions to explain site-to-site variability in the observed current plant communities. These authors revealed in 
a macro-study that young, weakly structured and poor soils favour higher palm basal area compared to trees (Emilio et al., 2014). The importance of the soils has been also proved in a local scale by Vegas-Vilarrúbia and López Laseras (2008) who tested the importance of edaphic conditions to interpret the large b-diversity of the lower Orinoco Delta plain that can be observed today. It is possible that the nature and quality of the formed soils favoured the arrival of Mauritia and the increase of Euterpe. In this sense, finer-grain sediments accumulation resulted from the delta progradation could have formed water-saturated (or poorly drained) sediments, and the combination with a decrease in organic matter (Fig. 3) might have favoured the Mauritia establishment (Aslan et al., 2003; Urrego, 2018). Whatever the nature of the sediment prior and after the sea-level stabilisation, a change in its characteristics is evident by the zonation resulted in the geochemical data (Fig. 3). The potential socioeconomic and ecological threats of current and future sea-level rise to deltas have been already highlighted by Vegas-Vilarrúbia and Rull (2016). Our study shows the local habitat disappearance resulted at least partially from the Holocene sea-level rise, which could be used as past analogue for future scenarios (Vegas-Vilarrúbia et al., 2011; Rull et al., 2013).

After the disappearance of coastal-like elements, another dramatic event in the Caño Tigre record was registered with the expansion of Mauritia at the expenses of the mixed-forest between 3800 and 2900 cal yr BP. Based on the Cariaco Ti curve, this period registered the maximum amplitude of the climatic trends during the Holocene caused by an increased ENSO variability that included several precipitation minima during this period, and was preceded by a strong El Niño (Haug et al., 2001). According to Haug et al. (2001), such amplitudes are comparable to the difference between the Younger Dryas and the Holocene Thermal Maximum, and it is striking that the Mauritia expansion occurred exactly coeval to this climatic event (Fig. 8). These results are in agreement with Urrego (2018), which has suggested a positive relationship between ENSO driven shortduration droughts and Mauritia. Similar palm swamp flourishment as the one occurred in the present study has been also previously reported and interpreted as evidence of relatively high water 
table (Behling and Lima da Costa, 2001). Thus, a potential influence of the soil type present (watersaturated or poorly drained) should be taken into account. Moving onwards on the temporal frame, the Cariaco record is characterised by wetter conditions during the Medieval Warm Period (MWP: 1.05-0.7 cal kyr BP), and this is also reflected in Caño Tigre record, although more subtly, by the synchronous increase in aquatic elements (Figs. 5, 7 and 8). However, the trends observed in the PCA axis scores do not agree with the climatic conditions inferred by the Cariaco record (Fig. 8). It is suggested that once the Mauritia swamp expanded around $3800 \mathrm{cal} \mathrm{yr} \mathrm{BP,} \mathrm{the} \mathrm{clays} \mathrm{trend} \mathrm{is}$ responding to the fine sediment captured by the Mauritia roots, obscuring any regional climate signal. The importance of the soils ontogeny (and therefore, of the local processes) in the present record is also shown in the RDAs made with the XRD and rock-magnetism data, with the biological samples (fossil pollen) ordered by age (Fig. 7). Our data are also in agreement with geomorphological studies showing the onset of Caños Mánamo and Pedernales as the principal distributaries of the northwest delta by distributary avulsion around $3000 \mathrm{cal}$ yr BP, coeval to the final establishment of Mauritia-dominance (Aslan et al., 2003).

Around 700 cal yr BP, a shift towards drier conditions started in Cariaco that culminated with several precipitation minima during the Little Ice Age (LIA; Haug et al., 2001). The present record is marked at this time snapshot by the sudden appearance and increase of several taxa that altered the composition and possibly the structure of the plant community (Fig. 5). This period is also characterised in Caño Tigre by an increase in the charcoal record and in the concentration of lowcoercivity minerals, which would agree with the climatic scenario inferred from Cariaco (Fig. 8). Besides Cariaco, other palaeoecological studies show shifts in climatic conditions around 700 cal yr BP (e.g., Behling et al., 2001; Carrillo-Bastos et al., 2010). Apart from the climatic trends, in the Orinoco Delta, Muller (1959) mentioned a previous work that evidenced a shift of the main Orinoco discharge from the eastern Delta towards Macareo and Boca Vagre estuaries at that time. 


\subsection{Human occupancy in the NW Orinoco Delta}

The presence of large indigenous populations in the Orinoco region was noticed by the earliest European explorers in the 16th and 17th centuries (Huber, 1995a). Even nowadays, Orinoquia is the homeland of 26 different Amerindian groups (Gassón, 2002). Palaeoecological studies can provide important evidence of past human presence or activities, and this information is especially valuable for those regions where archaeological research is limited (Montoya, 2018), as it is the Orinoco Delta. Amongst the most used proxies to infer past human impact in palaeoecological research is the fire record, even in the absence of impacts on the vegetation (Behling and Lima da Costa, 2000). Nevertheless, human presence and impact in the landscape has also been evidenced in the absence of fire use in coastal savannah environments (Iriarte et al., 2012). In this sense, multi-proxy studies (including for instance phytoliths, macro-fossils, or biomarkers) providing independent lines of anthropic evidence are encouraged to avoid too simplistic or even wrong inferences, as fire can have a climatic origin too (Siegel et al., 2015). An exception to this climatic origin of fires would be the wettest regions of northwestern Amazonia, where fire ignition is often undoubtedly humanmade (Montoya et al., in press).

Last 700 yr were characterised in the Caño Tigre record by a high fire incidence. As already mentioned, this increase coincided with a climatic shift towards drier conditions so a climate role should not be disregarded. Given the high charcoal values attained in the record and the current precipitation regime in the zone ( $>1500 \mathrm{~mm} \mathrm{yr}^{-1}$ without a marked dry season), we propose that the drier conditions could have favoured the fuel biomass availability. However, as showed by the continuous and increasing trend, we suggest that the ignition source of these fires was probably human occupation, with the burning of the plant material being favoured by the drier climatic conditions. Our suggestion of coupled human and climatic forces as responsible for the fire increase is also in agreement with the research performed so far in nearby ancient sites. In this sense, 
archaeological literature shows an important movement for eastern South American peoples starting at 500 Common Era (CE), with the Arauquinoid peoples migrating from Middle Orinoco towards the delta, the Antilles and the Guianas coast around 600e700 CE (Navarrete, 2008). Once the Arauquinoid started their migration down through the river, they mixed with Cedeñoid groups in the Delta, and mixed Cedeñoid-Arauquinoid-Valloid groups sailed toward Trinidad and the Antilles (Rostain, 2008). Closer to the present study area, the Mora site in central Delta was characterised by integrated elements of the Barrancoid and Arauquinoid traditions dated around 1000-1500 CE (Voorhies et al., 1981).

On the contrary, the oldest interval registered in the Caño Tigre record was related to more stable climatic conditions, and the presence of a mixed forest with coastal-like vegetation and some disturbance elements (i.e., Chenopodiaceae/Amaranthaceae, Cecropia, Monolete psilate). The most likely driver of such vegetation opening or clearing recorded on Zone OR18-1 is fire, as this period is characterised by the highest values of macrocharcoal of the entire sequence (Fig. 5). Despite the lack of additional proxies, it is suggested that this fire record was highly likely human-made, as it coincided with the wettest period of the interval studied (Fig. 8). The southeastern Caribbean (including southern islands and the mainland coast of Venezuela) has provided some evidence of ancient peoples (Siegel et al., 2015). The Archaic period has been described as a period of sparse but continuous inhabitation of the coastal areas forming an Archaic arc that included the southern Caribbean islands and the Venezuelan mainland coast (including the Gulf of Paria) until at least the Guianas and Brazil at the South (Antczak et al., 2019; Sanoja and Vargas, 1999). It has been suggested that the Archaic period in the coastal areas could have lasted longer than in the more inland locations due to geographic isolation (with stepped slopes and hills in the Venezuelan coast and islands). However, they might have had sporadic or even regular contacts with (inland) potterymakers depending on the proximity. During the Mesoindian period (7000-5000 yr BP, equivalent to Archaic) there was a transition from mammals' hunters to socio-economic tribal formation, defining 
diverse economic and sociocultural strategies. Within the subsistence strategies described for the eastern Venezuelan coast during the Archaic period, the following could have been adopted by the potential inhabitants of Caño Tigre: (i) gathering of endemic species in the Sucre coast mangroves (7000-4000 yr BP), (ii) fishermen and hunters related to eastern Venezuelan coast gatherers, or (iii) sea shore and deep water fishermen and sea shell gatherers, although the first remains for this last type appeared later (Navarrete, 2008). Towards the south, palaeoindian and archaic shell mounds were commonly found in western Guiana littorals, especially between the Orinoco Delta and Essequibo river, with relatively sparse inhabitation during the initial period and main subsistence based on shellfish, fishing and hunting, but also using a wide range of plants including palms (Plew, 2009; Rostain, 2008, 2009). In addition, previous palaeoecological records in N Brazil have argued possible Archaic human occupancy based on the charcoal record in similar environments to the present study site (Behling and Lima da Costa, 2001). It is suggested that in Caño Tigre record, coastal peoples were likely occupying the location, and once the seaward progradation of the sediment started, these ancient people abandoned the area. However, more multi- and interdisciplinary research is needed in order to validate or reject this working hypothesis. In case the coastal-peoples occupation is proved, the land abandonment following the combination of drivers including sea-level rise and drier conditions would have profound consequences in terms of the projected climatic scenarios and the current inhabitants of the delta (IPCC, 2013; Vegas-Vilarrúbia and Rull, 2016). On the other hand, based on the evidence obtained so far, a causal link in the synchronicity between the disappearance of fires (land abandonment) and the appearance and establishment of Mauritia in the surroundings remains elusive (Rull and Montoya, 2014).

Given the abundance of archaeological remains near the study site altogether, it is proposed that Caño Tigre location was probably populated at least in the mid-Holocene and during the last millennium by different cultures with diverse subsistence strategies. The above suggestions of human presence and their relationship between their dynamics and the environment are not 
examples of environmental determinism, as formerly proposed for some lowland South American cultures (Meggers, 1954; Lathrap, 1970). Such interpretation should be taken as a working hypothesis of some of the potential strategies used by past peoples when facing environmental events and the interplay with the natural dynamics of the ecosystems in where they lived. Nevertheless, given the absence of shell mounts or other archaeological evidence, this hypothesis should be considered with caution.

\section{Conclusions}

The palaeoecological study of the mid-Holocene dynamics of Caño Tigre vegetation has shown the forested nature of the landscape for the last 6200 years. However, this forest dramatically changed its composition twice during the interval studied, showing a rapid response of the individual species, but more gradual shifts as plant community. Swamp or rainforest with coastal-like elements characterised the location until approximately $5400 \mathrm{cal}$ yr BP, when drier conditions were inferred from Cariaco and the sea-level was already stabilised, which promoted sediment accumulation and the transition to a fluvial floodplain environment. The shoreline progradation favoured seaward migration of the coastal-like elements of the forest, and the nature of the sediment formed likely allowed the arrival and establishment of Mauritia stands and the occurrence of a mixed-swamp forest in this floodplain. Between 3800 and 2900 cal yr BP, during a period of climatic instability, Mauritia undertook an expansion that culminated with its absolute dominance upon the vegetation, establishing a less diverse palm-swamp in the study site. This community was completely established around 3000 yr ago, when the present-day main tributaries of the northwestern sector of the delta (i.e., Mánamo) appeared. Although similar to the present-day community, additional plant elements arrived to the study site around 700 years ago that finally shaped the current landscape. This last period was also marked by an increase in the fire regime. Archaeological evidence and the climatic inferences made from previous works point to a likely human contribution to the origin of 
this fire trend, possibly the arrival of the Arauquinoid culture to the study site. An ancient human occupancy in the area has been also suggested for the Mesoindian or Archaic period, between 6200 and $5400 \mathrm{cal}$ yr BP, when the coastline was about $30 \mathrm{~km}$ closer than nowadays, which would probably have had some coastal affinities and subsistence lifestyle. Nevertheless, more research with multi-proxy and interdisciplinary approach is mandatory in order to validate these working hypotheses. Given the importance of local conditions including delta ontogeny in both present and previous works on wetlands, careful must be taken before extrapolating results of a given wetland/delta to a supra-regional scale in terms of palaeoclimate and biological responses. Concerning climate during the $6200 \mathrm{yr}$ interval studied, it is remarkable the lack of significant delays of Caño Tigre's plant communities showing fast ecological responses to the climatic events or shifts registered in Cariaco. This research shows the high dynamism and sensitivity of these tropical plant communities in facing climatic shifts, so special attention to the potential responses they may develop in the near future as consequences of the ongoing climate change scenario should be paid. In this sense, the inferred socio-ecological shifts of increased ENSO and sea-level changes have been noteworthy. Finally, the present study shows the importance of undertaking multi-proxy approaches and frame them in an interdisciplinary context for acquiring a more precise picture of past landscape dynamics.

\section{Acknowledgements}

This study has been funded by BBVA Foundation (ref. BIOCON 08-031) to V. Rull, and the Spanish Ministry of Economy and Competitivity (Juan de la Cierva Incorporación contract, ref. IJCI-2015-24273) and the Catalan Agency for Universities and Research AGAUR and the EU programme Marie Curie COFUND (Beatriu de Pinòs - Marie Curie COFUND fellowship, ref.: 2014 BP-B 00094) to E. Montoya. Special thanks to the Fundación Instituto Botánico de Venezuela

Dr Tobías Lasser, the Eco-Camp Lodge staff (especially Karim, Edison, Darwin and the local Warao 
guide Santana), and Josy Carbón, Yaroslavi Espinoza and Tania Ballesteros for their help during field work. Núria Cañellas-Boltà performed the laboratory treatment of the modern samples and Charlie Foster contributed to the macrocharcoal analysis. Unless specified, all the analyses performed (XRD, rock-magnetism, palynology) were carried out at the facilities of the Institute of Earth Science Jaume Almera (ICTJA-CSIC). The authors want to thank the editors of Quaternary Science Reviews for their invitation to submit the manuscript, especially to José S. Carrión and two anonymous reviewers for their useful comments. 


\section{References}

Antczak, A.T., Buffeet, L.A.L., Antczak, M.M., Rull, V., 2019. Early indigenous occupations of Margarita island and the Venezuelan Caribbean. In: Hofman, C.L., Antczak, A.T. (Eds.), Early Settlers of the Insular Caribbean. Dearchaizing the Archaic. Sidestone Press, Leiden, pp. 131-146.

APG, I.V., 2016. An update of the Angiosperm Phylogeny Group classification for the orders and families of flowering plants: APG IV. Bot. J. Linn. Soc. 181, 1-20.

Aslan, A., White, W.A., Warne, A.G., Guevara, E.H., 2003. Holocene evolution of the western Orinoco delta, Venezuela. Geol. Soc. Am. Bull. 115, 479-498.

Behling, H., 2001. Late Quaternary environmental changes in the Lagoa da Curuça region (eastern Amazonia, Brazil) and evidence of Podocarpus in the Amazon lowland. Veg. Hist. Archaeobotany $10,175-183$.

Behling, H., Lima da Costa, M., 2000. Holocene environmental changes from the Rio Curuá record in the Caxiuaña region, eastern Amazon basin. Quat. Res. 53, 369-377.

Behling, H., Lima da Costa, M., 2001. Holocene vegetational and coastal environmental changes from the Lago Crispim record in northeastern Pará State, eastern Amazonia. Rev. Palaeobot. Palynol. 114, 145-155.

Behling, H., Cohen, M.C.L., Lara, R.J., 2001. Studies on Holocene mangrove ecosystem dynamics of the Bragança peninsula in north-eastern pará, Brazil. Palaeogeogr. Palaeoclimatol. Palaeoecol. $167,225-242$. 
Bennett, K.D., 1996. Determination of the number of zones in a biostratigraphical sequence. New Phytol. 132, 155-170.

Blaauw, M., 2010. Methods and code for “classical” age-modelling of radiocarbon sequences. Quat. Geochronol. 5, 512-518.

Bloemendal, J., King, J.W., Hall, F.R., Doh, S.J., 1992. Rock magnetism of Late Neogene and Pleistocene deep-sea sediments: relationship to sediment source, diagenetic processes and sediment lithology. J. Geophys. Res. Solid Earth 97, 4361-4375.

Bush, M.B., Weng, M.B., 2006. Introducing a new (freeware) tool for palynology. J. Biogeogr. 34, 377-380.

Carrillo-Bastos, A., Islebe, G.G., Torrescano-Valle, N., Gonzáles, N.E., 2010. Holocene vegetation and climate history of central Quintana Roo, Yucatán península, Mexico. Rev. Palaeobot. Palynol. 160, 189-196.

Chung, F.H., 1974. Quantitative interpretation of X-ray diffraction patterns of mixtures. I. Matrixflushing method for quantitative multicomponent analysis. J. Appl. Crystallogr. 7, 519-525.

Clark, J.S., Royall, P.D., 1995. Particle-size evidence for source areas of charcoal accumulation in late Holocene sediments of eastern North American lakes. Quat. Res. 43, 80-89.

Cohen, M.C.L., Ruiz Pessenda, L.C., Behling, H., Rossetti, D.F., França, M.C., Guimarães, J.T.F., Friaes, Y., Smith, C.B., 2012. Holocene palaeoenvironmental history of the Amazonian mangrove belt. Quat. Sci. Rev. 55, 50-58. 
Colinvaux, P.A., De Oliveira, P.E., Moreno, J.E., 1999. Amazon Pollen Manual and Atlas. Harwood Academic Publishers, Amsterdam.

Emilio, T., Quesada, C.A., Costa, F.R.C., Magnusson, W.E., Schietti, J., Feldpausch, T.R., Brienen, R.J.W., Baker, T.R., Chave, J., Álvarez, E., Araújo, A., Bánki, O., Castilho, C.V., Honorio, C.,E.N., Killeen, T.J., Malhi, Y., Oblitas Mendoza, E.M., Monteagudo, A., Neill, D., Parada, G.A., PeñaCruz, A., Ramirez-Angulo, H., Schwarz, M., Silveira, M., ter Steege, H., Terborgh, J.W., Thomas, R., Torres-Lezama, A., Vilanova, E., Phillips, O.L., 2014. Soil physical conditions limit palm and tree basal areas in Amazonian forests. Plant Ecol. Divers. 7, 215-229.

Evans, M.E., Heller, F., 2003. Environmental Magnetism. Academic Press, San Diego, CA.

Faegri, K., Iversen, J., 1989. In: Faegri, K., Kaland, P.E., Krzywinski, K. (Eds.), Textbook of Pollen Analysis, fourth ed. John Wiley \& Sons, New York, NY, p. 328.

Finsinger, W., Morales-Molino, C., Gałka, M., Valsecchi, V., Bojovic, S., Tinner, W., 2017. Holocene vegetation and fire dynamics at crveni potok, a small mire in the Dinaric Alps (Tara national Park, Serbia). Quat. Sci. Rev. 167, 63-77.

Flantua, S.G.A., Hooghiemstra, H., Grimm, E.C., Behling, H., Bush, M.B., González-Arango, C., Gosling, W., Ledru, M.-P., Lozano-García, S., Maldonado, A., Prieto, A., Rull, V., Van Boxel, J.H., 2015. Updated site compilation of the Latin American pollen database. Rev. Palaeobot. Palynol. 223, 104-115. 
França, M.C., Francisquini, M.I., Cohen, M.C.L., Pessenda, L.C.R., Rossetti, D.F., Guimarães, J.T.F., Smith, C.B., 2012. The last mangroves of Marajó Island - eastern Amazon: impact of climate and/or relative sea-level changes. Rev. Palaeobot. Palynol. 187, 50-65.

França, M.C., Alves, I.C.C., Cohen, M.C.L., Rossetti, D.F., Pessenda, L.C.R., Giannini, P.C.F., Lorente, F.L., Buso Junior, A.A., Bendassolli, J.A., Macario, K., 2016. Millennial to secular timescale impacts of climate and sea-level changes on mangroves from the Doce River Delta, Southeastern Brazil. Holocene 26, 1733-1749.

França, M.C., Pessenda, L.C.R., Cohen, M.C.L., de Azevedo, A.Q., Fontes, N.A., Borges Silva, F., de Melo Jr., J.C.F., Piccolo, M.C., Bendassolli, J.A., Macario, K., 2019. Late-Holocene subtropical mangrove dynamics in response to climate change during the last millennium. Holocene 29, 445456.

García Casto, A.A., Heinen, H.D., 1999. Planificando el desastre ecológico: Impacto del cierre del caño Manamo para las comunidades indígenas y criollas del Delta Occidental (Delta del Orinoco, Venezuela). Antropologica 91, 31-56.

Gassón, R.A., 2002. Orinoquia: the archaeology of the Orinoco river basin. J. World Prehist. 16, 237-311.

Gassón, R.A., Heinen, H.D., 2012. ¿Existe un Warao Genérico?: Cuestiones Clave en la Etnografía y la Ecología Histórica del Delta del Orinoco y el Territorio Warao-Lokono-Paragoto. Tipití: J. Soc. Anthropol. Lowland South Am. 10, 37-64.

González, V., 2011. Los bosques del Delta del Orinoco. Biollania 10, 197-240. 
Grimm, E.C., Keltner, J., Cheddadi, R., Hicks, S., Lézine, A.-M., Berrío, J.C., Williams, J.W., 2007. Pollen methods and studies/Databases and their application. In: Elias, S.A. (Ed.), Encyclopedia of Quaternary Science. Elsevier, pp. 2521-2528.

Haug, G.H., Hughen, K.A., Sigman, D.M., Peterson, L.C., Röhl, U., 2001. Southward migration of the intertropical convergence zone through the Holocene. Science 293, 1304-1308.

Heinen, H.D., 1975. The Warao indians of the Orinoco Delta: an outline of their traditional economic organization and interrelation with the national economy. Antropológica 40, 25-55.

Heinen, H.D., 1988. Los Warao. In: Lizot, Jaques (Ed.), Los Aborígenes de Venezuela. Etnología contemporánea. Tomo III. Caracas. Fundación La Salle de Ciencias Naturales-Instituto Caribe de Sociología y Antropología, pp. 585-689.

Heinen, D.H., García-Castro, A., 2013. Arquitectura indígena venezolana y heterogeneidad Warao: una aclaración necesaria. Bol. Antropol. 85, 7-34.

Heinen, H.D., Lizarralde, R., Gómez, T., 1994-1996. El abandono de un ecosistema: el caso de los morichales del Delta del Orinoco. Antropológica 81, 3-36.

Hill, M.O., 1973. Diversity and evenness: a unifying notation and its consequences. Ecology 54, 427-432.

Hofmann, C.-C., 2002. Pollen distribution in sub-recent sedimentary environments of the Orinoco Delta (Venezuela) e an actuo-palaeobotanical study. Rev. Palaeobot. Palynol. 119, 191-217. 
Huber, O., 1995a. Geographical and physical features. Flora of the Venezuelan Guayana. In: Steyermark, J.A., Berry, P.E., Holst, B.K. (Eds.), Introduction, vol. 1. Missouri Botanical Garden Press, Missouri, pp. 1-62.

Huber, O., 1995b. Vegetation. Flora of the Venezuelan Guayana. In: Steyermark, J.A., Berry, P.E., Holst, B.K. (Eds.), Introduction, vol. 1. Missouri Botanical Garden Press, Missouri, pp. 97-160.

Huber, O., Zent, S., 1995. Indigenous people and vegetation in the Venezuelan Guayana: some ecological considerations. Sci. Guaianae 5, 37-64.

INE (Instituto Nacional de Estadística), 2015. XIV Censo General de Población y Vivienda 2011. Empadronamiento de la población indígena. INE, Caracas.

IPCC, 2013. In: Stocker, T.F., Qin, D., Plattner, G.-K., Tignor, M., Allen, S.K., Boschung, J., et al. (Eds.), Climate Change 2013: the Physical Science Basis. Contribution of Working Group I to the Fifth Assessment Report of the Intergovernmental Panel on Climate Change. Cambridge University Press, Cambridge, p. 1535.

Iriarte, J., Power, M.J., Rostain, S., Mayle, F.E., Jones, H., Watling, J., Whitney, B.S., McKey, D.B., 2012. Fire-free land use in pre-1492 Amazonian savannas. Proc. Natl. Acad. Sci. U.S.A. 109, 64736478.

Jowsey, P.C., 1966. An improved peat sampler. New Phytol. 65, 245-248.

Juggins, S., 2017. Rioja: Analysis of Quaternary Science Data. R Package. Available at: Version (0.9-15). http://cran.r-project.org/package1/4rioja. 
Khan, N.S., Ashe, E., Horton, B.P., Dutton, A., Kopp, R.E., Brocard, G., Engelhart, S.E., Hill, D.F., Peltier, W.R., Vane, C.H., Scatena, F.N., 2017. Drivers of Holocene sea-level change in the Caribbean. Quat. Sci. Rev. 155, 13-36.

Koch, A., Brierley, C., Maslin, M.M., Lewis, S.L., 2019. Earth system impacts of the European arrival and great dying in the Americas after 1492. Quat. Sci. Rev. 207, 13-36.

Lathrap, D.W., 1970. The Upper Amazon. Thames and Hudson, Southampton.

Meggers, B.J., 1954. Environmental limitation on the development of culture. Am. Anthropol. 56, 801-824.

Meyers, P.A., 1994. Preservation of elemental and isotopic source identification of sedimentary organic matter. Chem. Geol. 114, 289-302.

Montoya, E., 2018. Historia de la Amazonía: Contribución de la paleoecología al debate de ocupación precolombina y sus efectos en el ecosistema. Ecosistemas 27, 18-25.

Montoya, E., Lombardo, U., Aymard, G.A., Levis, C., ter Steege, H., Mayle, F.E., 2019. Human contribution to Amazonian diversity: pre-Columbian legacy to current plant communities. In: Rull, V., Carnaval, A. (Eds.), Neotropical Diversification. Springer, Berlin (in press).

Muller, J., 1959. Palynology of recent Orinoco Delta and shelf sediments: reports of the Orinoco shelf expedition; Volume 5. Micropaleontology 5, 1-32. 
Myers, N., Mittermeier, R.A., Mittermeier, C.G., da Fonseca, G.A.B., Kent, J., 2000. Biodiversity hotspots for conservations priorities. Nature 403, 853-858.

Navarrete, R., 2008. The prehistory of Venezuela-not necessarily an intermediate area. In: Silverman, H., Isbell, W.H. (Eds.), Handbook of South American Archaeology. Springer, New York, pp. 429-458.

Oksanen, J., Guillaume Blanchet, F.R.K., Legendre, P., Minchin, P.R., O'Hara, B.R., Simpson, G.L., Solymos, P., Henry, M., Stevens, H., Wagner, H., 2013. Vegan: Community Ecology Package. R Package. Available at:, Version 2.0-10. https:// cran.r-project.org/package1/4vegan.

Plew, M.G., 2009. Pleistocene-early Holocene environmental change: implications for human adaptative responses in the Guianas. In: Whitehead, N.l., Alemán, S.W. (Eds.), Anthroplogies of Guayana: Cultural Spaces in Northeastern Amazonia. The University of Arizona Press, Tucson, pp. 23-35.

R Core Team, 2018. R: A Language and Environment for Statistical Computing. R Foundation for Statistical Computing, Vienna. Available online at: https://www. R-project.org.

Reimer, P.J., Bard, E., Bayliss, A., Beck, J.W., Blackwell, P.G., Bronk Ramsey, C., Buck, C.E., Cheng, H., Edwards, R.L., Friedrich, M., Grootes, P.M., Guilderson, T.P., Haflidason, H., Hajdas, I., Hatté, C., Heaton, T.J., Hoffmann, D.L., Hogg, A.G., Hghen, K.A., Kaiser, K.F., Kromer, B., Manning, S.W., Niu, M., Reimer, R.W., Richards, D.A., Scott, E.M., Southon, J.R., Staff, R.A., Turney, C.S.M., van der Plicht, J., 2013. IntCal 13 and Marine 13 radiocarbon age calibration curves 0-50,000 years cal BP. Radiocarbon 55, 1869-1887. 
Rivera-Collazo, I.C., 2019. Gone with the waves: sea-level rise, ancient territories and the socioenvironmental context of Mid-Holocene maritime mobility in the pan-Caribbean region. In: Hofman, C.L., Antczak, A.T. (Eds.), Early Settlers of the Insular Caribbean. Dearchaizing the Archaic. Sidestone Press, Leiden, pp. 47-56.

Rondón de Rodríguez, C., Elizalde, G., Maza, I.J., 2012. Modelo pedogeomorfológico de un área del Delta Superior del río Orinoco afectada por el cierre del caño Mánamo, Venezuela. Rev. Científica UDO Agrícola 12, 338-352.

Rostain, S., 2008. The archaeology of the Guianas: an overview. In: Silverman, H., Isbell, W.H. (Eds.), Handbook of South American Archaeology. Springer, New York, pp. 185-216.

Rostain, S., 2009. Between Orinoco and Amazon: the ceramic age in the Guianas. In: Whitehead, N.l., Alemán, S.W. (Eds.), Anthroplogies of Guayana: Cultural Spaces in Northesastern Amazonia. The University of Arizona Press, Tucson, pp. 36-54.

Roubik, D.W., Moreno, J.E.P., 1991. Pollen and Spores of Barro Colorado Island. Monographs in Systematic Botany. Missouri Botanical Garden, St. Louis, MO.

Rull, V., 1987. A note on pollen counting in palaeoecology. Pollen Spores 29, 47-e480.

Rull, V., 1998a. Biogeographical and evolutionary considerations on Mauritia (Arecaceae), based on palynological evidence. Rev. Palaeobot. Palynol. 100, 109-122.

Rull, V., 1998b. Modern and Quaternary palynological studies in the Caribbean and Atlantic coasts of northern South America: a paleoecologically-oriented review. Bol. Soc. Venez. Geol. 23, 5-24. 
Rull, V., 2009. Microrefugia. J. Biogeogr. 36, 481-484.

Rull, V., Montoya, E., 2014. Mauritia flexuosa palm swamp communities: natural or human-made? A palynological study of the Gran Sabana region (northern South America) within a neotropical context. Quat. Sci. Rev. 99, 17-33.

Rull, V., Vegas-Vilarrúbia, T., de Pernía, N.E., 1999. Palynological record of an early-mid Holocene mangrove in Eastern Venezuela. Implications for sea-level rise and disturbance history. J. Coast. Res. 15, 496-504.

Rull, V., Vegas-Villarrúbia, T., Nogué, S., Montoya, E., 2008. Bureaucratic obstruction of conservation science in the Guayana highlands. Conserv. Biol. 22, 508-509.

Rull, V., Montoya, E., Nogué, S., Vegas-Vilarrúia, T., Safont, E., 2013. Ecological palaeoecology in the neotropical Gran Sabana region: long-term records of vegetation dynamics as a basis for ecological hypothesis testing. Perspect. Plant Ecol. Evol. Syst. 15, 338-359.

Sanoja, M., Vargas, I., 1999. Orígenes de Venezuela. Regiones geohistóricas aborígenes hasta 1500 D.C. Imprenta Nacional (Caracas, Venezuela).

Siegel, P.E., Jones, J.G., Pearsall, D.M., Dunning, N.P., Farrell, P., Duncan, N.A., Curtis, J.H., Singh, S.K., 2015. Paleoenvironmental evidence for first human colonization of the eastern Caribbean. Quat. Sci. Rev. 129, 275-295.

Simpson, G.L., 2007. Analogue methods in palaeoecology: using the analogue package. J. Stat. Softw. 22 (2) https://doi.org/10.18637/jss.v022.i02. 
Simpson, G.L., 2012. Analogues methods in palaeolimnology. In: Birks, H.J.B., Lotter, A.F., Juggins, S., Smol, J.P. (Eds.), Tracking Environmental Change Using Lake Sediments, Volume 5: Data Handling and Numerical Techniques. Springer, Dordrecht, pp. 495-522.

Stockmarr, J., 1971. Tablets with spores used in absolute pollen analysis. Pollen Spores 16, 615621.

ter Steege, H., Pitman, N.C.A., Sabatier, D., Baraloto, C., Salomão, R.P., Guevara, J.E., Phillips, O.L., Castilho, C.V., Magnusson, W.E., Molino, J.-F., Monteagudo, A., Núñez Vargas, P., Montero, J.C., Feldpausch, T.R., Honorio Coronado, E.N., Killeen, T.J., Mostacedo, B., Vasquez, R., Assis, R.L., Terborgh, J., Wittmann, F., Andrade, A., Laurance, W.F., Laurance, S.G.W., Marimon, B.S., Marimon Jr., B.-H., Guimarães Vieira, I.C., Leão Amaral, I., Brienen, R., Castellanos, H., Cárdenas López, D., Duivenvoorden, J.F., Mogollón, H.F., de Almeida Matos, F.D., Dávila, N., GarcíaVillacorta, R., Stevenson Diaz, P.R., Costa, F., Emilio, T., Levis, C., Schietti, J., Souza, P., Alonso, A., Dallmeier, F., Duque Montoya, A.J., Fernandez Piedade, M.T., Araujo-Murakami, A., Arroyo, L., Gribel, R., Fine, P.V.A., Peres, C.A., Toledo, M., Aymard, C.G.A., Baker, T.R., Cerón, C., Engel, J., Henkel, T.W., Maas, P., Petronelli, P., Stropp, J., Zartman, C.E., Daly, D., Neill, D., Silveira, M., Ríos Paredes, M., Chave, J., Lima Filho, D.A., Jørgensen, P.M., Fuentes, A., Schöngart, J., Cornejo Valverde, F., Di Fiore, A., Jimenez, E.M., Peñuela Mora, M.C., Phillips, J.F., Rivas, G., van Andel, T.R., von Hildebrand, P., Hoffman, B., Zent, E.L., Malhi, Y., Prieto, A., Rudas, A., Ruschell, A.R., Silva, N., Vos, V., Zent, S., Oliveira, A.A., Schutz, A.C., Gonzales, T., Nascimento, M.T., RamirezAngulo, H., Sierra, R., Tirado, M., Umaña Medina, M.N., van der Heijden, G., Vela, C.I.A., Vilanova Torre, E., Vriesendorp, C., Wang, O., Young, K.R., Baider, C., Balslev, H., Ferreira, C., Mesones, I., Torres-Lezama, A., Urrego, L.E., Zagt, R., Alexiades, M.N., Hernandez, L., Huamantupa-Chuquimaco, I., Milliken, W., Palacios Cuenca, W., Pauletto, D., Sandoval, E.V., 
Gamarra, L.V., Dexter, K.G., Feeley, K., Lopez-Gonzalez, G., Silman, M.S., 2013. Hyperdominance in the Amazonian tree flora. Science 342, 1243092.

Tissot, C., Marius, C., 1992. Holocene evolution of the mangrove ecosystem in French Guiana: a palynological study. In: Singh, K.P., Singh, J.S. (Eds.), Tropical Ecosystems: Ecology and Management. Wiley Eastern Limited, New Delhi, pp. 333-347.

Thompson, R., Oldfield, F., 1986. Environmental Magnetism. Allen \& Unwin, Boston, MA.

Urrego, L.E., 2018. Cananguchales y manglares: humedales forestales de las zonas bajas tropicales, tan semejantes como contrastantes. Rev. Acad. Colomb. Cienc. Ex. Fis. Nat. 42, 80-95.

Urrego, L.E., Bernal, G., Polanía, J., 2009. Comparison of pollen distribution patterns in Surface sediments of a Colombian Caribbean mangrove with geomorphology and vegetation. Rev. Palaeobot. Palynol. 156, 358-375.

Urrego, L.E., González, C., Urán, G., Polanía, J., 2010. Modern pollen rain in mangroves from san Andres island, Colombian Caribbean. Rev. Palaeobot. Palynol. 162, 168-182.

Urrego, L.E., Correa-Metrio, A., González, C., Castaño, A.R., Yokoyama, Y., 2013. Contrasting responses of two Caribbean mangroves to sea-level rise in the Guajira Peninsula (Colombian Caribbean). Palaeogeogr. Palaeoclimatol. Palaeoecol. 370, 92-102.

Vedel, V., Behling, H., Cohen, M., Lara, R., 2006. Holocene mangrove dynamics and sea-level changes in northern Brazil, inferences from the Taperebal core in northeastern Pará state. Veg. Hist. Archaeobotany 15, 115- 123. 
Vegas-Vilarrúbia, T., 2000. Zonation pattern of an isolated mangrove community at Playa Medina, Venezuela. Wetl. Ecol. Manag. 8, 9-17.

Vegas-Vilarrúbia, T., López Laseras, P., 2008. Edaphic patterns as related to ß-diversity in swamp forests and meadows of the Lower Orinoco Delta plain (Venezuela). Wetlands 28, 616-631.

Vegas-Vilarrúbia, T., Rull, V., 2016. Undervalued impacts of sea-level rise: vanishing deltas. Front. Ecol. Evol. 4, 77.

Vegas-Vilarrúbia, T., Ponce, M.E., Gómez, O., Mora, L., 2007. Wetland vegetation of the lower Orinoco Delta plain (Venezuela): a preliminary approach. Amazoniana 3/4, 35-61.

Vegas-Vilarrúbia, T., Baritto, F., López, P., Meléan, G., Ponce, M.E., Mora, L., Gómez, O., 2010. Tropical histosols of the lower Orinoco Delta, features and preliminary quantification of their carbon storage. Geoderma 155, 208-288.

Vegas-Vilarrúbia, T., Rull, V., Montoya, E., Safont, E., 2011. Quaternary palaeoecology and nature conservation: a general review with some examples from the Neotropics. Quat. Sci. Rev. 30, 23612388.

Vegas-Vilarrúbia, T., Hernández, E., Rull, V., Rull-Vegas, E., 2015. The Orinoco megadelta as a conservation target in the face of the ongoing and future sea level rise. Sci. Total Environ. 515-516, 129-142.

Vila, M.A., 1970. El delta del Orinoco. Rev. Geogr. 4, 92-97. 
von Post, L., 1916. Om skogsträdpollen i sydsvenska torfmosslagerföljder. Geol. Fören. Stockh. Förhandlingar 38, 384-390.

Voorhies, B., Wagner, E., Arvelo, L., 1981. Mora: un yacimiento arqueológico en el Bajo Delta del Orinoco, Venezuela. Antropológica 55, 31-50.

Warne, A.G., Meade, R.H., White, W.A., Guevara, E.H., Gibeaut, J., Smyth, R.C., Aslan, A., Tremblay, T., 2002a. Regional controls on geomorphology, hydrology, and ecosystem integrity in the Orinoco Delta, Venezuela. Geomorphology 44, 273-307.

Warne, A.G., Guevara, E.H., Aslan, A., 2002b. Late quaternary evolution of the Orinoco delta, Venezuela. J. Coast. Res. 18, 225-253.

White, W.A., Warne, A.G., Guevara, E.H., Aslan, A., Tremblay, T.A., Raney, J.A., 2002. Geoenvironments of the northwest Orinoco delta, Venezuela. Interciencia 27, 521-528.

Whitlock, C., Larsen, C., 2001. Charcoal as a fire proxy,. In: Smol, J.P., Birks, H.J.B., Last, W.M. (Eds.), Tracking Environmental Change Using Lake Sediments. Terrestrial, Algal, and Siliceous Indicators, vol. 3, pp. 75e98 (Dordrecht: Kluwer).

Wilbert, W., Mandazen Soto, P., 1997. Integrative ecology. Antropologica 87, 3-18.

Yulianto, E., Rahardjo, A.T., Noeradi, D., Siregar, D.A., Hirakawa, K., 2005. A Holocene pollen record of vegetation and coastal environmental changes in the coastal swamp forest at Batulicin, South Kalimantan, Indonesia. J. Asian Earth Sci. 25, 1-8. 


\section{Figures:}

Fig. 1. Study area. A: North of South America showing the locations mentioned in the text (1: Cariaco Basin, 2: Gulf of Paria, 3: Trinidad, 4: Guianas coastal region, and 5: Amazon mouth). B: Orinoco Delta region, with main towns shown in yellow and main river channels or caños named in blue and italics. EVD: El Volcán Dam, 6: Mora archaeological site (Voorhies et al., 1981). C: Specific location of the study site, showing the closest village (in white) and the name of the main caños (blue and italics). Black dots and numbers in yellow refer to the location of the samples collected, being 15: modern sample CT0, 16: Modern sample CT3, 17: modern sample CT1, and 18: modern sample CT2 and sedimentary archive PATAM18A-12. Images modified from Google Earth.
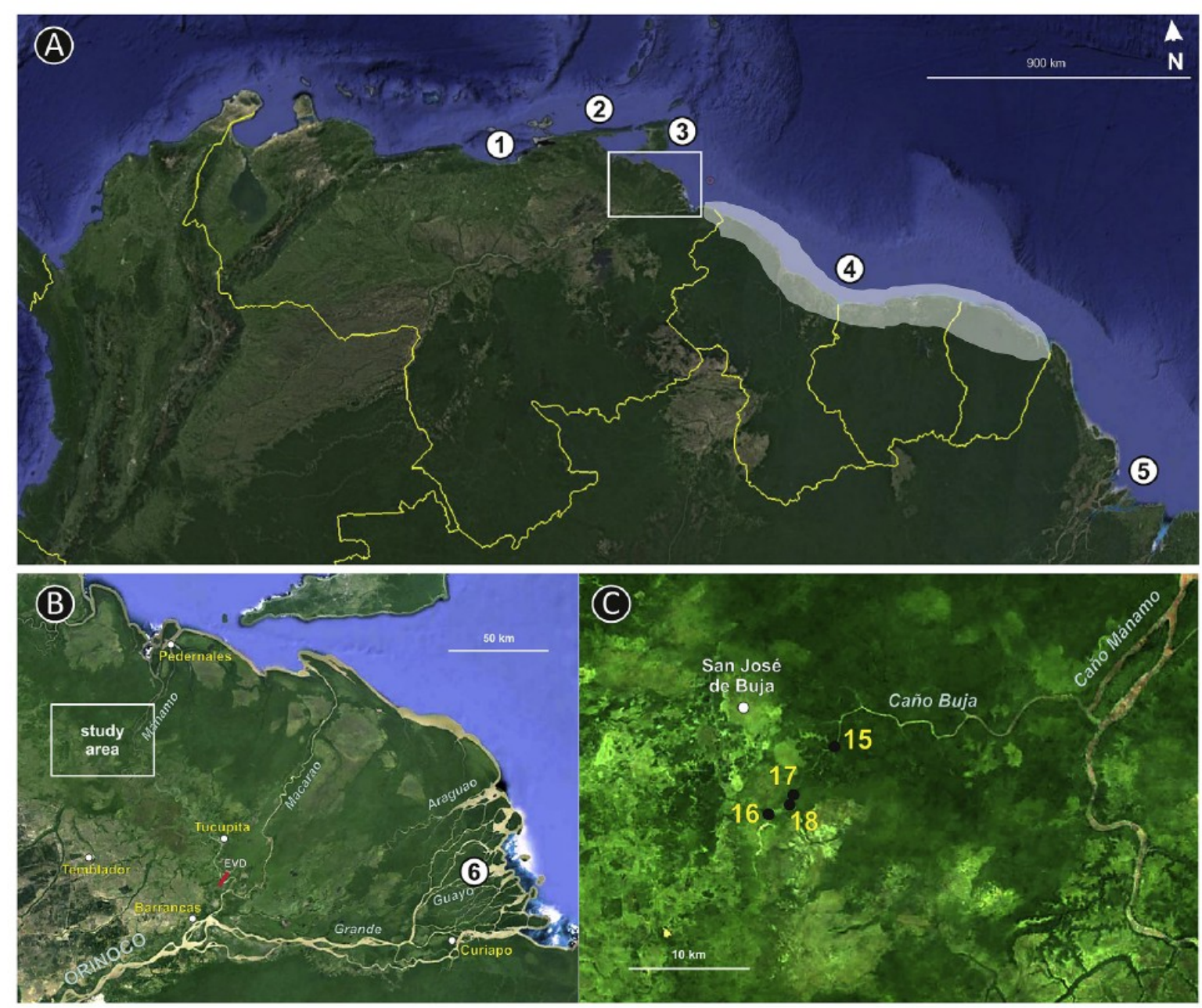
Fig. 2. Sediment description, radiocarbon $\left({ }^{14} \mathrm{C}\right)$ dates, and age-depth model of the sedimentary record PATAM18_A12. Colour legend used in the sediment description refers to subtle differences in the facies (composed by clays and peat) found, being silty clays with high content of organic matter (black), grey clay without peat (grey), peaty clay (brown), and light coloured clay with some peat (white).

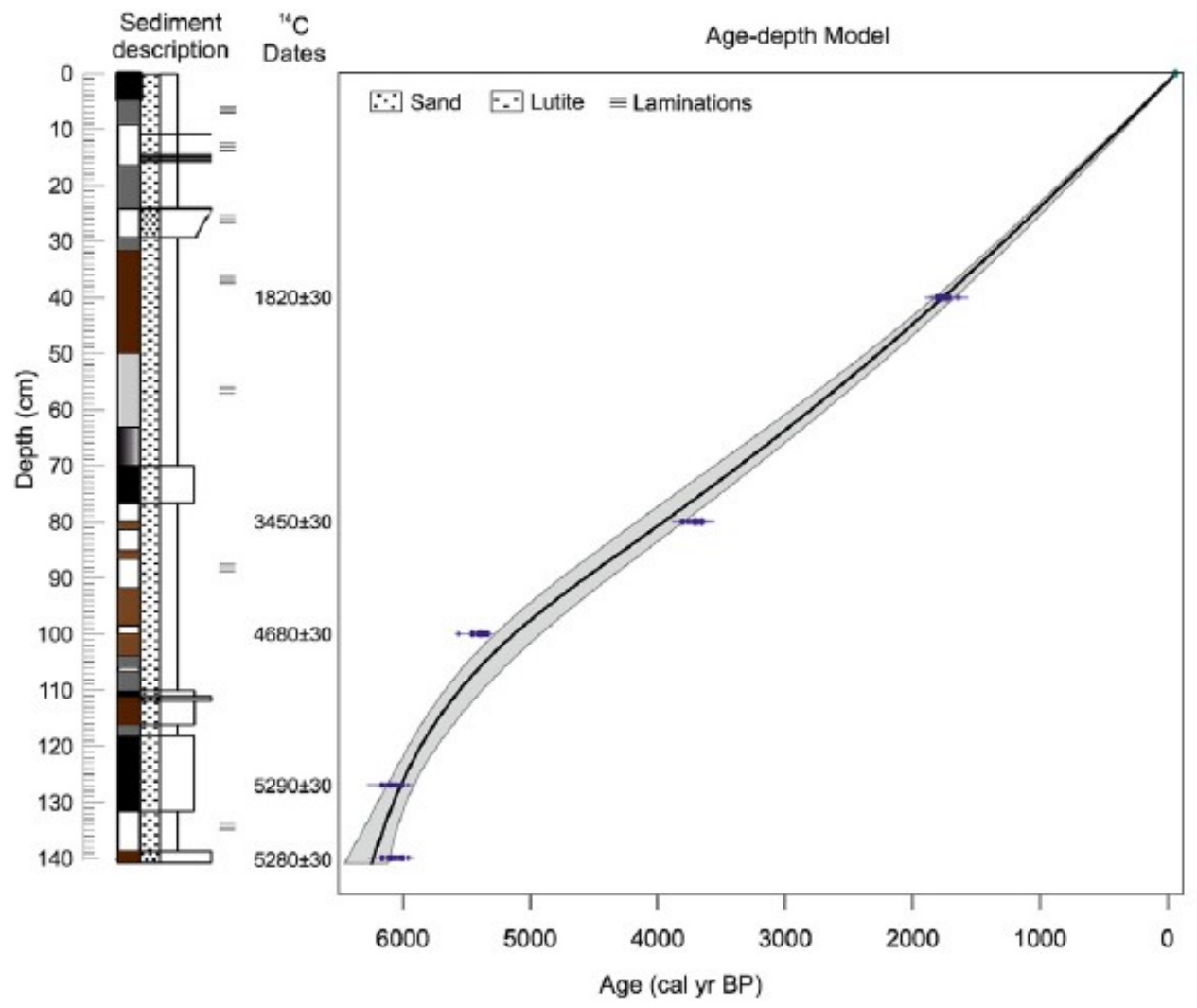


Fig. 3. Geochemical analyses. A: Identified mineral species and their temporal evolution. Data expressed in percentage with respect to dry weight (\% wt). From B to F: Downcore variation of concentration of low- and high-coercivity magnetic minerals together with the $S$ and the ARM/SIRM ratios that are proxies of the relative concentration of low versus high-coercivity magnetic minerals and of the magnetic grain size, respectively. G: Total carbon and nitrogen as well as their respective stable isotope composition of the bulk organic matter present in the studied record. Data expressed in per thousand (\%). Two values of $\delta^{13} \mathrm{C}$ were too high and saturated the curve (shown in grey bars).

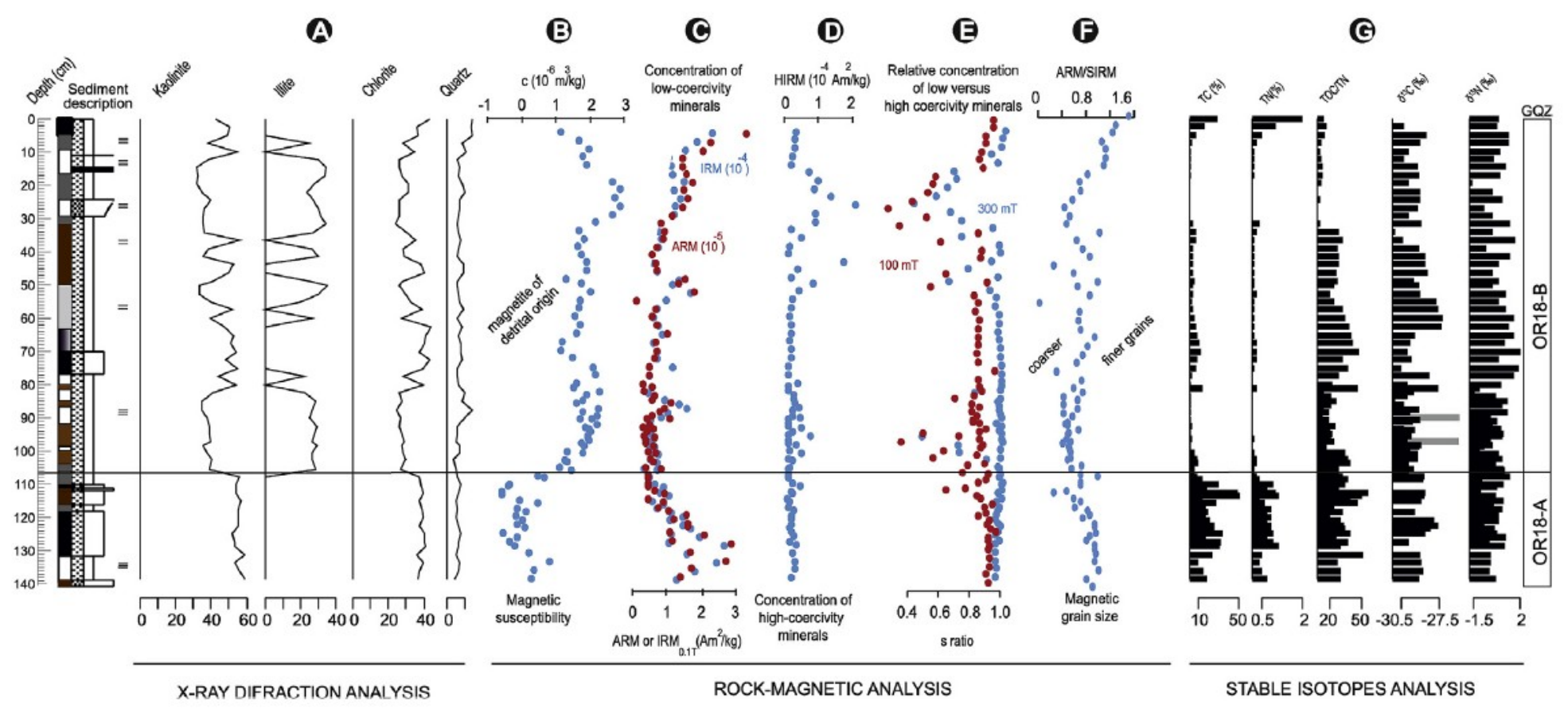


Fig. 4. Diagram of the palynomorphs registered in the modern samples analysed, expressed in percentages, and including macro- and microcharcoal particles expressed in concentration (particles $\mathrm{CC}^{-1}$ ) values. All the taxa percentages are shown with the same scale (equal width means equal \% values). Only taxa with percentages higher than $5 \%$ have been represented.

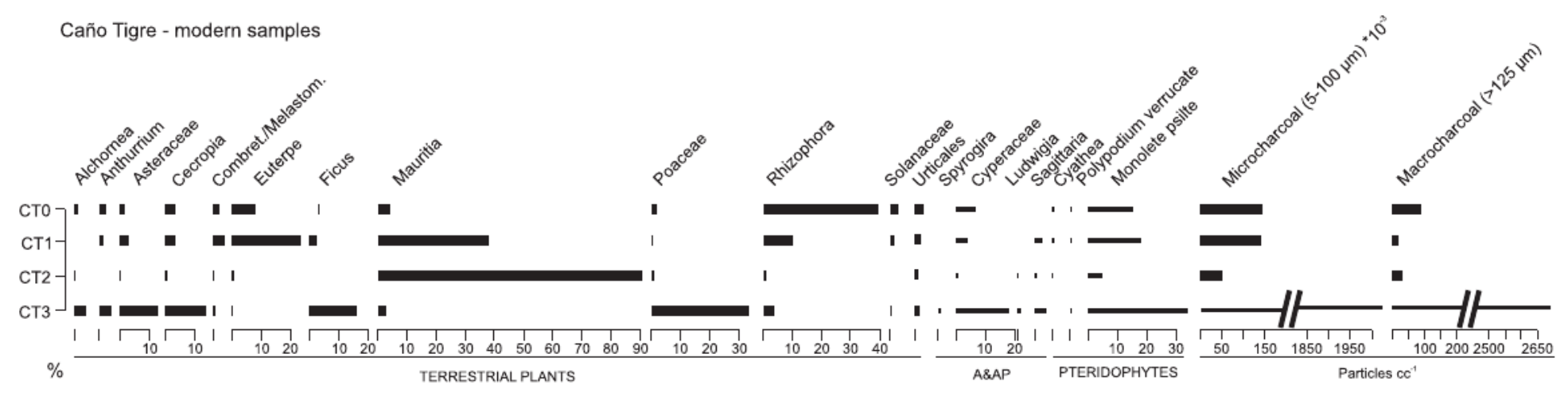


Fig. 5. Pollen diagram of the sedimentary record PATAM18_A12 expressed in percentages, including the stratigraphic column and charcoal particles expressed in concentration (particles $\mathrm{Cc}^{-1}$ ) values: referring macro- and micro-charcoal to the different methodologies explained in section 2.2. Only taxa occurring at percentages higher than $10 \%$ are represented. All the taxa percentages are shown with the same scale (equal width means equal \% values) and outline values represent x10 exaggeration. Colours refer to features of the taxa (Green: trees; Orange: palms; Purple: treelets, lianas or vines; Yellow: herbs; Brown: pteridophytes; Blue: algal and aquatic plants; Black: undefined).

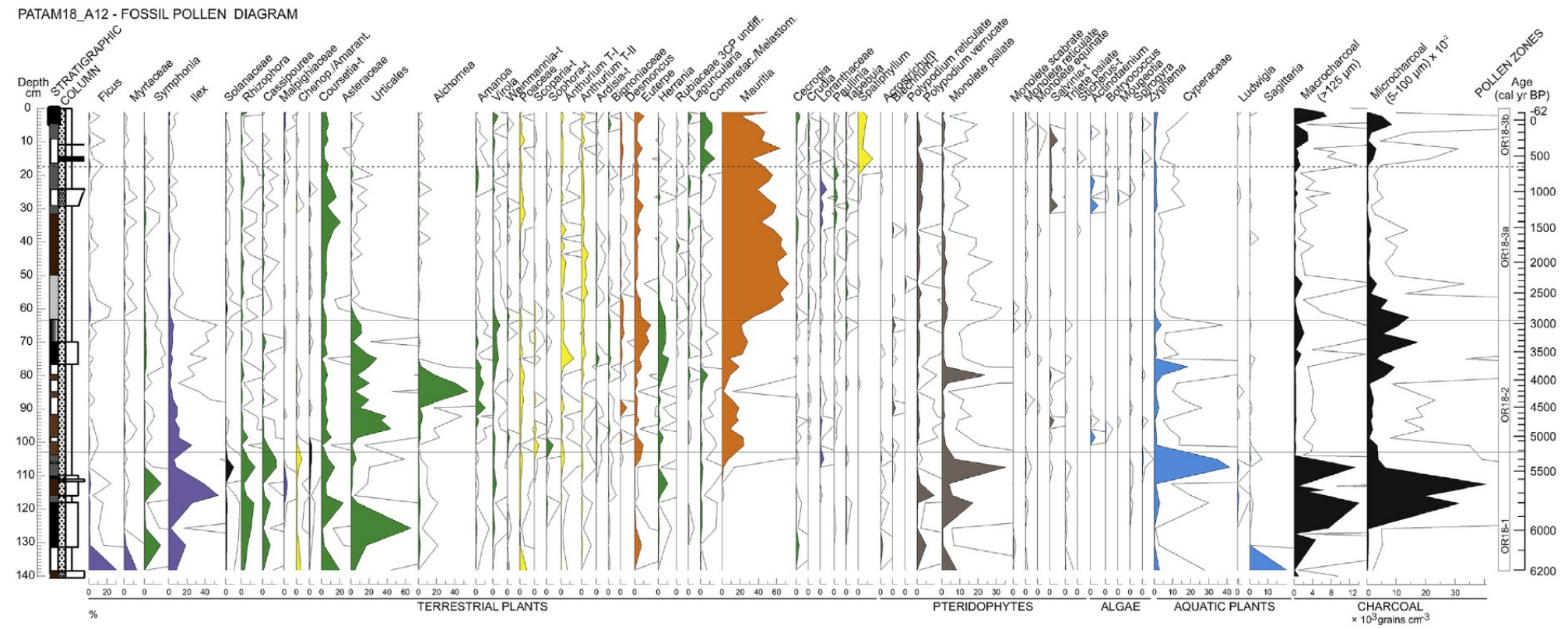


Fig. 6. Modern analogues analysis. A: AMCA, B: DCA, and C: Timetracker (in PCA). Sample colours in B refers to the main palynological zones and associated forest types: Blue (Zone OR18-1; swamp or rainforest) with coastal-like elements; Green (Zone OR18-2; mixed swamp forest); and Orange (Zone OR18-3; Mauritia palm-swamp).
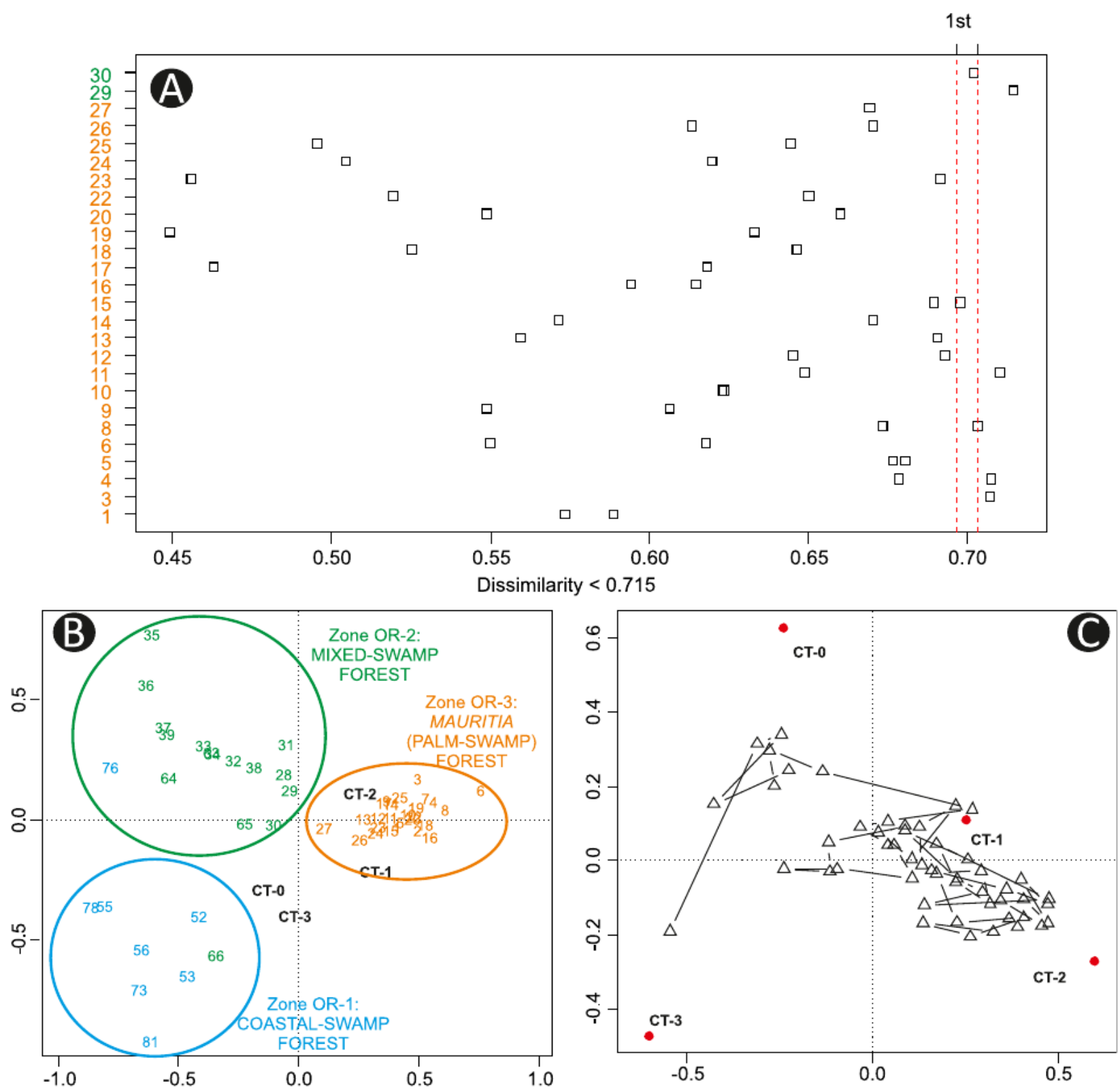
Fig. 7. RDA plot of the geochemical data (A: XRD; B: rock-magnetism) as environmental variables with biological data (fossil pollen samples), and C: Meyers (1994) plot for stable isotopes. Samples' colours follow Fig. 6.
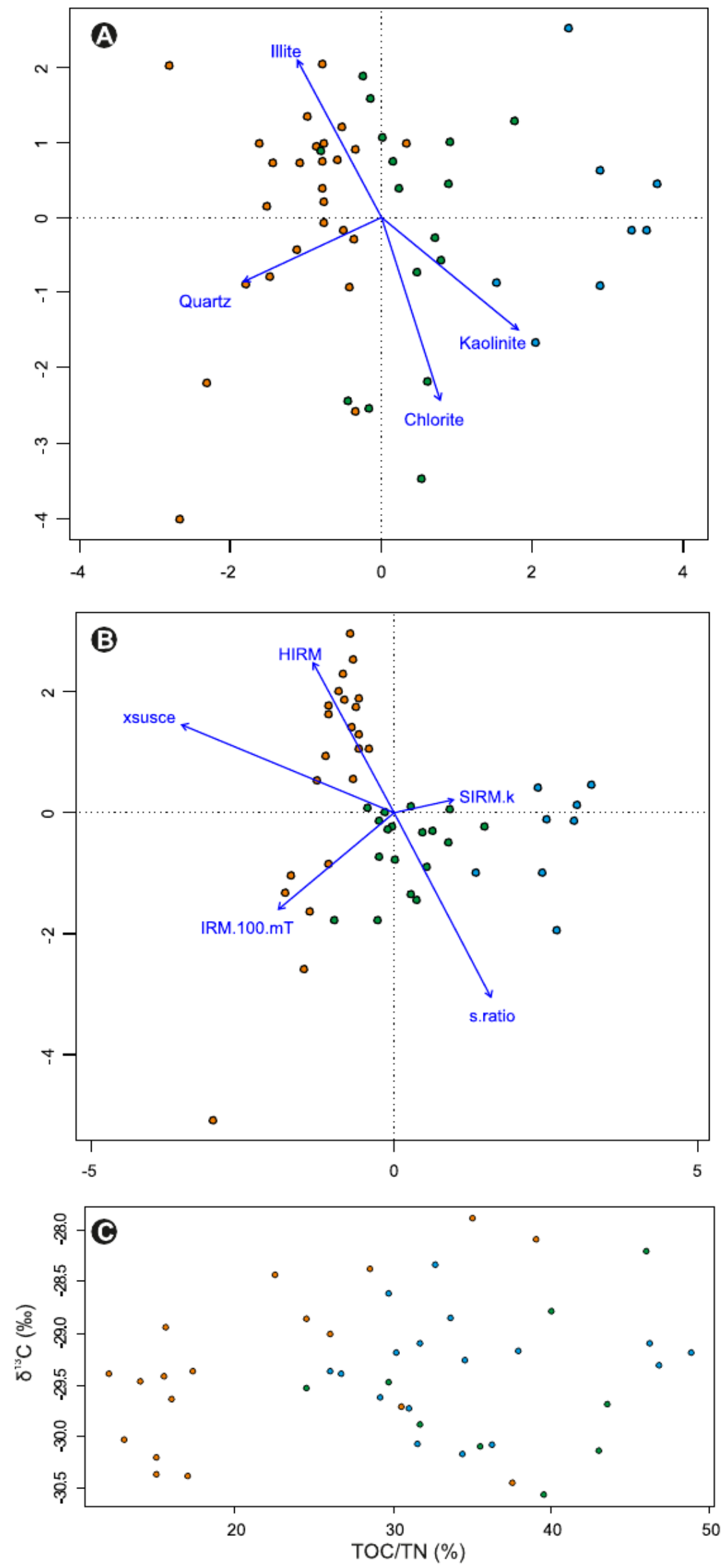
Fig. 8. Discussion-summary figure that includes: (A) the pollen zones obtained for the sedimentary archive PATAM18_A12; (B) the Ti curve obtained in the Cariaco basin record, previously published in Haug et al. (2001) (data downloaded from NOAA database). LIA: Little Ice Age; (C) the diversity values calculated following Hill (1973); (D) the scores obtained for the PCA first axis of the XRD data, which represents the relationship between kaolinite and chlorite ( $\mathrm{K}+\mathrm{C}$; positive) and illite (negative) values; (E) the macrocharcoal curve expressed in influx values (particles $\mathrm{cm}^{-2}$ $\mathrm{yr}^{-1}$ ); and (F) the pollen sum of terrestrial pollen taxa (in \%), with colours legend following Fig. 6.
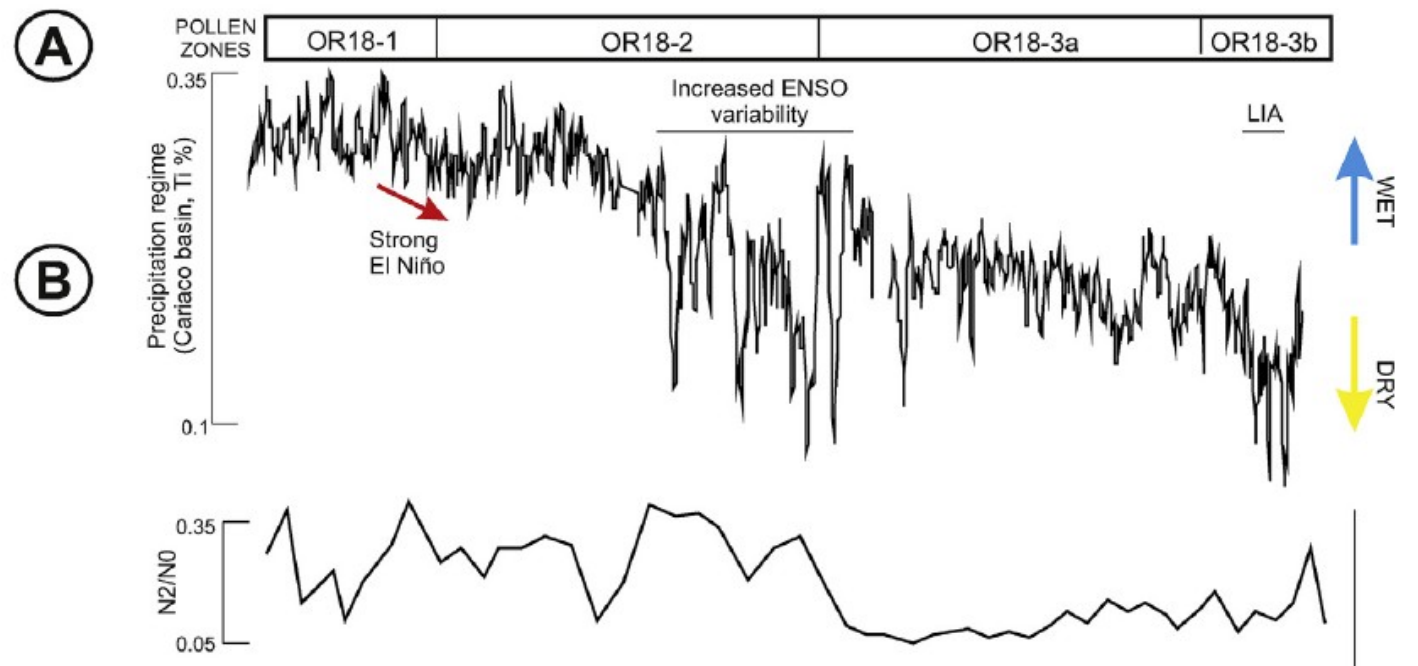

(c)

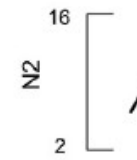

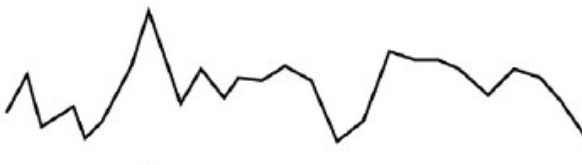

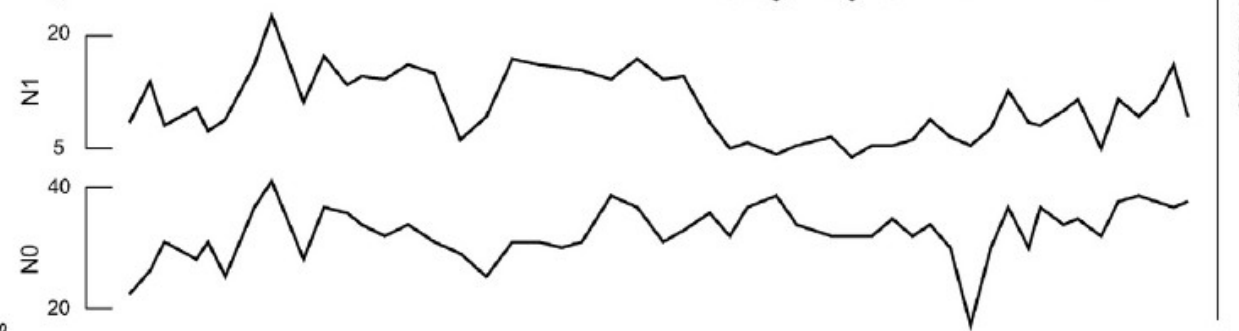

(D)

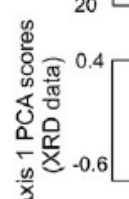<smiles>C1=CCCC=1</smiles>
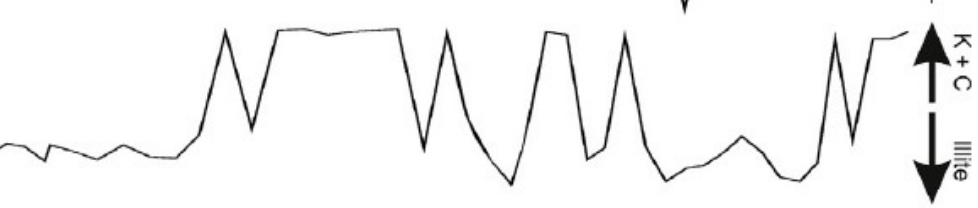

(E)

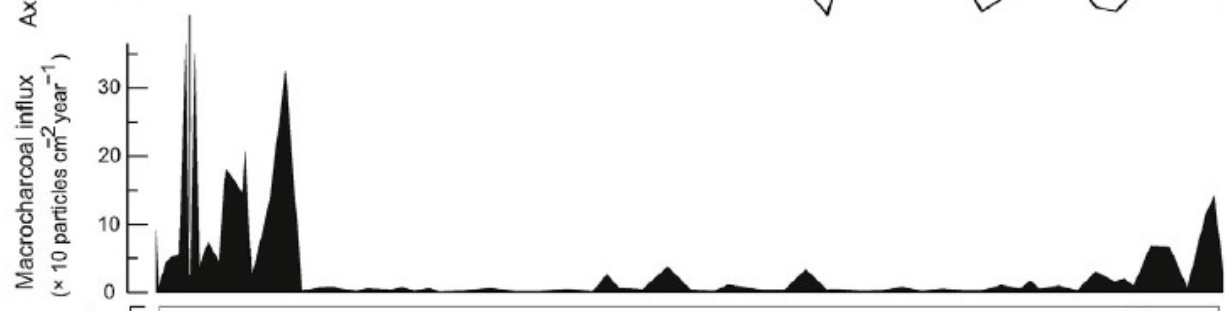

(F)

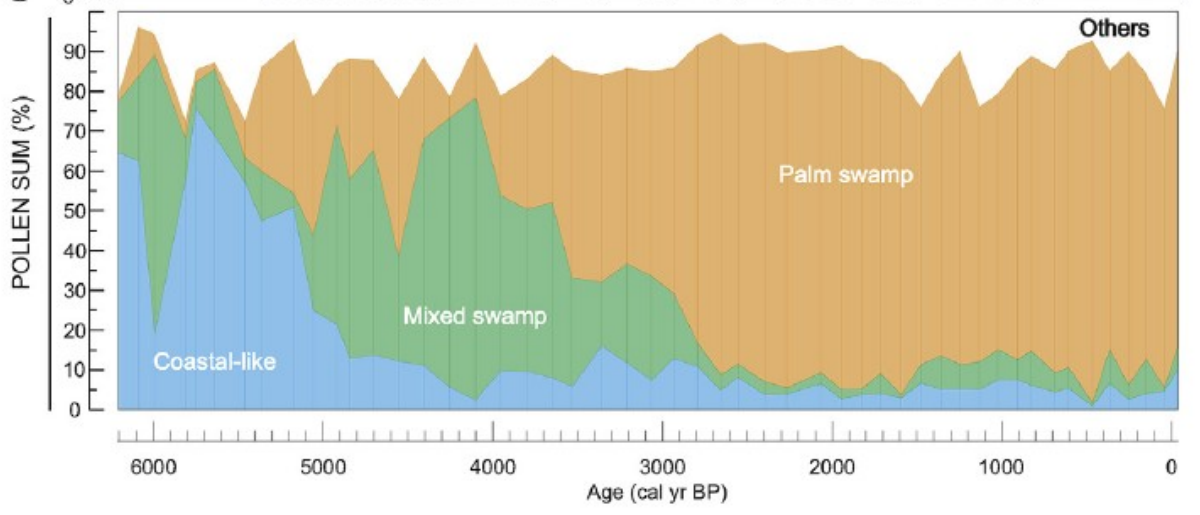


Table 1. AMS radiocarbon dates used for the age-depth model. WA: weighted average.

\begin{tabular}{|c|c|c|c|c|c|c|c|}
\hline Laboratory & Sample & $\begin{array}{l}\text { Depth } \\
\text { (cm) }\end{array}$ & $\begin{array}{l}\text { Sampl } \\
\text { e type }\end{array}$ & $\begin{array}{l}\text { Age (yr } \\
\left.\mathrm{C}^{14} \mathrm{BP}\right)\end{array}$ & $\begin{array}{l}{ }^{13} \mathrm{C} /{ }^{12} \mathrm{C} \\
\text { ratio } \\
(\%)\end{array}$ & $\begin{array}{l}\text { Age (cal } \\
\text { yr BP) } 2 \sigma\end{array}$ & $\begin{array}{l}\text { Age (cal yr } \\
\text { BP) } \\
\text { estimation } \\
\text { (WA) }\end{array}$ \\
\hline Beta-347774 & $\begin{array}{l}\text { PATAM18D1 } \\
\text { /40 }\end{array}$ & 40 & $\begin{array}{l}\text { Pollen } \\
\text { residue }\end{array}$ & $1820 \pm 30$ & -29 & $\begin{array}{l}1694- \\
1825\end{array}$ & 1763 \\
\hline Beta-347775 & $\begin{array}{l}\text { PATAM18D2 } \\
/ 80\end{array}$ & 80 & $\begin{array}{l}\text { Pollen } \\
\text { residue }\end{array}$ & $3450 \pm 30$ & -28.5 & $\begin{array}{l}3637- \\
3779\end{array}$ & 3952 \\
\hline Beta-347776 & $\begin{array}{l}\text { PATAM18D3 } \\
* / 10\end{array}$ & 100 & $\begin{array}{l}\text { Pollen } \\
\text { residue }\end{array}$ & $4680 \pm 30$ & -27.9 & $\begin{array}{l}5319- \\
5429\end{array}$ & 5123 \\
\hline Beta-342033 & $\begin{array}{l}\text { PATAM18D3 } \\
\text { /46 }\end{array}$ & 127 & $\begin{array}{l}\text { Pollen } \\
\text { residue }\end{array}$ & $5290 \pm 30$ & -28.7 & $\begin{array}{l}5990- \\
6181\end{array}$ & 6013 \\
\hline Beta-342044 & $\begin{array}{l}\text { PATAM18D3 } \\
* / 49\end{array}$ & 140 & $\begin{array}{l}\text { Pollen } \\
\text { residue }\end{array}$ & $5280 \pm 30$ & -26.6 & $\begin{array}{l}5987- \\
6128\end{array}$ & 6229 \\
\hline
\end{tabular}


Table 2. Main features of the modern samples collected in different environments along Caño Tigre (CT).

\begin{tabular}{|c|c|c|c|c|}
\hline Sample & Coordinates & Elevation & $\begin{array}{l}\text { Vegetation } \\
\text { community }\end{array}$ & Major taxa \\
\hline CT0 & $\begin{array}{l}9^{\circ} 32^{\prime} 44.3^{\prime \prime} \mathrm{N}- \\
62^{\circ} 38^{\prime} 53.8^{\prime \prime} \\
W\end{array}$ & $6 \mathrm{~m}$ asl & $\begin{array}{l}\text { Disturbed delta; } \\
\text { abandoned Warao } \\
\text { settlement }\end{array}$ & $\begin{array}{l}\text { Mauritia flexuosa, } \\
\text { Montrichardia arborescens, } \\
\text { Blechnum sp., Poaceae, } \\
\text { Rizophora mangle, Eichhornia } \\
\text { crassipes, Cyperaceae }\end{array}$ \\
\hline CT1 & $\begin{array}{l}9^{\circ} 30^{\prime} 28.0 " \mathrm{~N}- \\
62^{\circ} 40^{\prime} 50.1^{\prime \prime} \\
W\end{array}$ & $10 \mathrm{~m}$ bsl & Palm forest & $\begin{array}{l}\text { Mauritia flexuosa, Euterpe } \\
\text { oleracea, Chusquea sp., } \\
\text { Montrichardia arborescens }\end{array}$ \\
\hline CT2 & $\begin{array}{l}9^{\circ} 30^{\prime} 08.2^{\prime \prime} \mathrm{N}- \\
62^{\circ} 40^{\prime} 55.3^{\prime \prime} \\
W\end{array}$ & $13 \mathrm{~m} \mathrm{bsl}$ & $\begin{array}{l}\text { Deltaic } \\
\text { monoespecific } \\
\text { palm stand }\end{array}$ & $\begin{array}{l}\text { Mauritia flexuosa, Mimosoidae, } \\
\text { Desmoncus orthocanthos, } \\
\text { Montrichardia sp. }\end{array}$ \\
\hline CT3 & $\begin{array}{l}9^{\circ} 29^{\prime} 31.7^{\prime \prime} \mathrm{N}- \\
62^{\circ} 41^{\prime} 55.2^{\prime \prime} \\
W\end{array}$ & $3 \mathrm{~m}$ asl & $\begin{array}{l}\text { Monoespecific } \\
\text { palm stand; close } \\
\text { to a current } \\
\text { Warao settlement }\end{array}$ & $\begin{array}{l}\text { Mauritia flexuosa, Ficus sp., } \\
\text { Montrichardia arborescens, } \\
\text { Bignoniaceae, Eichhornia } \\
\text { crassipes }\end{array}$ \\
\hline
\end{tabular}

